\title{
US Fiscal Cycle and the Dollar
}

\author{
ZHENGYANG JIANG*
}

February 15, 2019

\begin{abstract}
I document a new pattern unique to the US: When the US fiscal condition is strong, the dollar is strong and continues to appreciate in the next 3 years. This pattern makes the dollar an extraordinary asset, because most assets have lower prices when their expected returns increase. A stylized model accounts for this pattern, provided that the US fiscal cycle comoves with the US investors' risk premium. This model further predicts that the US fiscal cycle explains the forward premium puzzle, the term premium, the dollar carry trade, and currency return momentum, all confirmed in the data. What makes this fiscal-currency comovement unique to the US? I conjecture its exceptional external balance sheet and its special role as the hegemon issuer of the world's reserve assets are contributing factors, and provide suggestive evidence from cross-border capital flows and official foreign reserves.
\end{abstract}

* Department of Finance, Kellogg School of Management, Northwestern University, 2211 Campus Drive, Evanston, IL 60208. Email: zhengyang.jiang@kellogg.northwestern.edu. Website: https://sites.google.com/site/jayzedwye/. For comments and discussions, I thank Torben Andersen, John Cochrane, Nicolas Crouzet, Ian Dew-Becker, Konstantin Milbradt, Sergio Rebelo, Tano Santos, Jesse Schreger, Viktor Todorov, Stijn Van Nieuwerburgh, Rob Richmond, and seminar participants at Northwestern Kellogg, Columbia Business School, and CUHK Business School. 
The US government surplus-to-debt ratio measures the net fraction of its outstanding debt the US government pays down in each quarter. As shown in Figure 1, it is persistent, reflecting a slow-moving fiscal cycle. Since the late 1980s, a higher US government surplusto-debt ratio is associated with a stronger dollar and predicts a higher expected return on the dollar against foreign currencies. The US fiscal cycle explains $50 \%$ of the low-frequency variation in the dollar's value, captures $43 \%$ of the variation in the dollar's forward premium, and predicts $18 \%$ of the variation in the dollar's excess return in the next 4 quarters.

This pattern contrasts the negative relationship between asset prices and expected returns common in asset pricing. For example, a stronger demand for US dollar safe assets corresponds to a stronger dollar and predicts a lower expected return on the dollar in the future (Valchev (2017); Jiang, Krishnamurthy and Lustig (2018)). These patterns also differ by their frequencies: The safe asset demand coincides with the quarter-to-quarter and the yearto-year variations in the dollar's value, whereas the US fiscal cycle comoves with the dollar's

\section{Figure 1. US Government Surplus-to-Debt Ratio and the Dollar.}

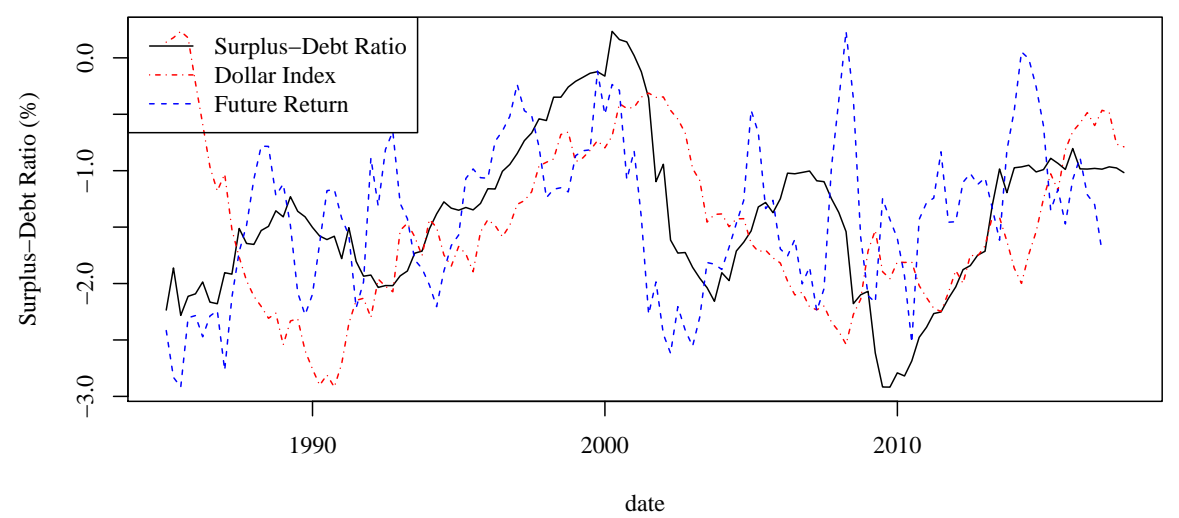

Note: The surplus-to-debt ratio is the ratio between the US government surplus in each quarter and the quantity of US government debt at the beginning of the quarter. The dollar index is the log real tradeweighted dollar index relative to its value 20 quarters ago. The future return is the average log excess return of the dollar against 10 foreign currencies in the next 4 quarters. The dollar index and the future return are rescaled to fit the figure. 
value at the frequency of multiple years.

This pattern is also unique to the US: Higher government surplus-to-debt ratios are not correlated with higher nominal exchange rates in 8 out of 10 other developed countries, and do not predict higher currency returns in 9 out of 10 other developed countries.

I conjecture that this pattern is driven by the comovement between the US fiscal cycle and the US investors' risk appetite: When the US experiences an expansion, the US fiscal condition strengthens and the US investors' risk appetite improves. On the one hand, currency value reflects the present value of government budget surpluses. During expansions, a stronger US fiscal condition raises the nominal value of the dollar.

On the other hand, foreign currencies are risky from the perspective of the US investors. As they are less risk-averse during US expansions, they require a lower risk compensation for holding foreign currencies, decreasing foreign currencies' risk premia with respect to the dollar. Equivalently, the dollar has a higher expected real return with respect to foreign currencies (Lustig, Roussanov and Verdelhan (2014)).

In this way, the dollar has a higher nominal value and a higher expected real return during US expansions. Price stickiness helps connect the dollar's nominal value and real expected return. In a reduced-form new-Keynesian model, I embed this fiscal-currency comovement and replicate my empirical finding.

My model further predicts that the US fiscal cycle explains the forward premium, the term premium, the dollar carry trade, and currency return momentum. In my model, (1) when the US fiscal condition is stronger, the dollar has a higher forward premium. A higher forward premium predicts the dollar to have higher expected returns in the short run and lower expected returns in the long run. (2) At the same time, since the US investors are less risk-averse, they also require lower compensation for holding long-term dollar bonds, lowering the dollar's term premium. (3) A trading strategy that bets on the dollar against foreign currencies when the US fiscal condition is strong generates a high Sharpe ratio, and explains the dollar carry trade's return. (4) The dollar's exchange rate has a time-series 
momentum that disappears when the US fiscal cycle is controlled for. All of these predictions are confirmed in the data.

This argument about the fiscal-currency comovement could be applied to any country. What makes it unique to the US? I highlight two contributing factors. First, the US has an exceptional external balance sheet: The US investors mainly hold foreign risky assets denominated in foreign currencies, while foreign investors mainly hold safe US liabilities denominated in US dollars (Gourinchas et al. (2010); Gourinchas and Rey (2014); Dou and Verdelhan (2015); Maggiori (2017); Maggiori, Neiman and Schreger (2018)).

Consistent with my assumption that the US fiscal cycle comoves with the US investors' risk appetite, I find that US investors also buy more foreign stocks and less foreign bonds when the US fiscal condition is stronger. This finding suggests that the US fiscal cycle comoves with the US investors' risk appetite for a broader set of foreign risky assets. In contrast, since foreign investors mainly hold safe US liabilities to hedge against global recessions, the US dollar is unlikely to be a risky investment from their perspective ${ }^{1}$. This imbalance in cross-border investment aligns the US investors' risk appetite with foreign currencies' risk premia, whereas foreign investors' demand for the US dollar is more driven by a flight to safety.

Second, dollar safe assets and the US Treasury in particular are international reserve assets (Farhi and Maggiori (2017); He, Krishnamurthy and Milbradt (2019); Jiang, Krishnamurthy and Lustig (2019)). Since the US fiscal condition affects the commitment of the US government to maintaining the value of these reserve assets during global recessions, the US fiscal cycle is tightly connected to the stability of the international monetary system and to the global risk appetite.

Consistent with this connection, I find that the US fiscal cycle is positively correlated with the dollar's share in the world's official foreign exchange reserves, and explains a large fraction

\footnotetext{
${ }^{1}$ In fact, the dollar has a lower expected return during global recessions (Engel and West (2010); Jiang, Krishnamurthy and Lustig (2018))
} 
of the variation in the currency composition of these official reserves. To the extent that the dollar's share in official reserves measures the world's confidence in the dollar reserve assets, this finding suggests that the US fiscal cycle comoves with this confidence and therefore the valuation of the US dollar.

In summary, I document a unique relationship between the US fiscal cycle and the US dollar. This pattern can be explained by the cyclical behaviors of the US fiscal condition and the US investors' risk appetite, which also offer an organizing principle for other asset pricing anomalies. I conjecture that the exceptional external balance sheet of the US links the US business cycle to foreign currencies' risk premia, and the special role of the US as the hegemon issuer of international reserve assets strengthens the link between the US fiscal cycle and the dollar's value. These conjectures are more speculative than the rest of analysis in this paper, and their further development is left for future work.

\section{A. Related Literature}

My paper highlights the comovement between the US investors' countercyclical risk premium and the US fiscal cycle. Investors' risk premium has been shown to affect currency expected returns $^{2}$. Lustig, Roussanov and Verdelhan (2014) show that the countercyclical risk premium is the key to understand why the dollar's forward premium predicts the dollar's excess return against foreign currencies. However, most of these models associate a higher expected return on the dollar with a weaker dollar. In comparison, the mechanism in this paper simultaneously generates a higher expected return on the dollar and a stronger dollar.

On the other hand, the fiscal condition has been shown to affect currency value during currency crises and under the fiscal theory of the price level ${ }^{3}$. My paper finds the US fiscal

\footnotetext{
${ }^{2}$ Colacito and Croce (2011, 2013); Bansal and Shaliastovich (2013); Colacito et al. (Forthcoming) show how long-run risks affect exchange rates. Verdelhan (2010); Heyerdahl-Larsen (2014); Stathopoulos (2016) show how external habits affect exchange rates. Gourio, Siemer and Verdelhan (2013); Farhi and Gabaix (2016) consider rare-disaster risks. Hassan (2013); Martin (2013); Richmond (2016) use country size and trade network centrality to explain currency risk premia. Lustig and Verdelhan (2015); Chien, Lustig and Naknoi (2015); Dou and Verdelhan (2015) consider market incompleteness and segmented financial markets.

${ }^{3}$ Burnside, Eichenbaum and Rebelo (2001, 2003); Corsetti and Mackowiak (2001); Daniel (2001a) show
} 
cycle comoves with the dollar in a unique way, while foreign currencies' exchange rates are disconnected from fundamentals (Meese and Rogoff (1983); Backus and Smith (1993); Obstfeld and Rogoff (2000)). Moreover, my paper documents the relationship between the US fiscal cycle and other asset pricing anomalies, suggesting the comovement between the fiscal cycle and the risk premium is more general.

The US dollar has been studied from other perspectives. Valchev (2017); Jiang, Krishnamurthy and Lustig (2018) show that the supply and demand of dollar safe assets affect the dollar's value and expected return. Table 1 shows that my results are robust to controlling for the US Treasury basis and the US government debt-to-GDP ratio.

Gourinchas and Rey (2007, 2014); Gourinchas, Rey and Sauzet (2018) show the dollar's return is predicted by the US external imbalance. The US fiscal condition and its external imbalance are not correlated despite their potential link. Appendix Table B10 and B11 show my results are robust to controlling for the US current account-to-GDP ratio and the cyclically-adjusted imbalance (nxa), while nxa is also a strong predictor of the dollar's value.

Evans and Lyons (2002); Hau and Rey (2004, 2005); Froot and Ramadorai (2005); Fourel et al. (2015) show order flows and portfolio rebalancing motives also drive exchange rates. Relative to these factors, the US fiscal cycle drive the dollar at lower frequencies.

\section{Main Results}

\section{A. Data}

My sample contains 11 developed economies: Australia, Canada, Denmark, Germany, Japan, New Zealand, Norway, Sweden, Switzerland, the United Kingdom, and the United

how fiscal shocks affected nominal exchange rates during currency crises. The fiscal theory of the price level shows fiscal conditions are reflected by domestic price levels (Sargent and Wallace (1984); Leeper (1991); Woodford (1994); Sims (1994); Cochrane (2001, 2005, 2018b, 2017); Dupor (2000); Daniel (2001b)). Bolton and Huang (2017) introduce sovereign default and study the optimal financing decision of a government. Bénétrix and Lane $(2010,2011)$ show fiscal variables covary with output cycles and financial cycles. More recently, Liu (2016) shows that high government debt is correlated with high stock and credit risk premia, and Nguyen (2018) shows that high government debt forecasts low consumption growth and deflation. 
States. Data are quarterly. The main panel covers the period from 1988Q1 to 2017Q4.

Exchange rates and forwards rates are nominal, unless otherwise indicated. Government surpluses, government debt and GDP are obtained from Oxford Economics. US GDP is seasonally adjusted, but US government surplus and US government debt quantity are not. For robustness tests, I also obtain government surplus data from Federal Reserve Economic Data (FRED) and Thomson Reuters International Comparable Economics (TRICE).

The government surplus-to-debt ratio is defined as the ratio between the nominal government surplus in each quarter and the nominal quantity of government debt at the beginning of the quarter. This ratio measures the net fraction of its outstanding debt the US government pays down during each quarter. If this ratio is negative, the government has to issue additional debt to finance its budget deficit.

\section{B. Time-Series Regressions}

I aggregate the data into a single time-series by fixing the dollar as the base currency and taking the equal-weighted average of exchange rates and currency returns across foreign countries. Let $e_{t}$ denote the average log nominal exchange rate of the dollar against foreign currencies. It is the equal-weighted dollar index:

$$
e_{t} \stackrel{\text { def }}{=} \frac{1}{N} \sum_{i} e_{t}^{U S, i}
$$

Let $f p_{t}$ denote the average log forward premium of the dollar against foreign currencies, defined as the difference between the spot exchange rate and the 3-month forward:

$$
f p_{t} \stackrel{\text { def }}{=} \frac{1}{N} \sum_{i}\left(e_{t}^{U S, i}-f_{t}^{U S, i}\right) .
$$

If the covered interest rate parity holds, the forward premium equals to the interest rate differential between the US and foreign countries. 
Let $r_{t, k}$ denote the average log excess return of the dollar against foreign currencies in the next $k$ quarters. It is the sum of log quarterly exchange rate movements and log quarterly forward premia:

$$
r_{t, k} \stackrel{\text { def }}{=} e_{t+k}-e_{t}+\sum_{\tau=0}^{k-1} f p_{t+\tau} .
$$

I regress the dollar's nominal exchange rate $e_{t}$ and future excess return $r_{t, k}$ on the US government surplus-to-debt ratio in quarter $t$. I include the US Treasury basis, the US government debt-to-GDP ratio, and the dollar's forward premium as controls because the literature finds that they are related to risk premia or convenience yields (Fama (1984); Valchev (2017); Jiang, Krishnamurthy and Lustig (2018); Du, Im and Schreger (2018)):

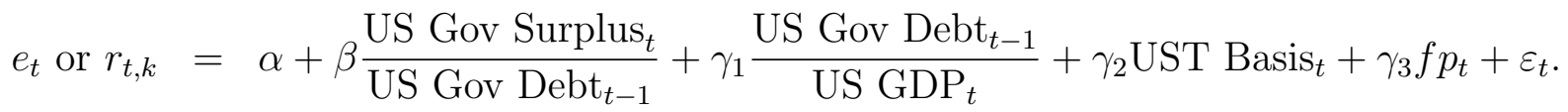

Table 1 reports the result. A higher US government surplus-to-debt ratio is associated with a stronger dollar today and predicts a higher expected return on the dollar in the next 2 quarters to 3 years. A $1 \%$ higher surplus-to-debt ratio is associated with a $10 \%$ stronger dollar, a further $5 \%$ higher excess return in the next year, and a $8 \%$ higher excess return in the next two years. In comparison, a more negative US Treasury basis and a lower US government debt-to-GDP ratio are associated with a stronger dollar today and predicts a lower expected return on the dollar in the next 3 years.

The result is similar if I restrict the sample to the time series of each foreign country, as shown in Appendix Table B1. This result also holds if the dependent variable is the dollar's nominal exchange rate movement $e_{t+k}-e_{t}$ : Appendix Table B3 shows that a $1 \%$ higher US government surplus-to-debt ratio also predicts a $5 \%$ dollar appreciation in the next year, and $8 \%$ in the next two years.

I report the following robustness tests in the Appendix. (1) I reconstruct the dollar's 


\section{Table 1 -What Explains The Dollar's Value and Future Return.}

\begin{tabular}{|c|c|c|c|c|c|c|}
\hline & \multicolumn{6}{|c|}{ Dependent variable: } \\
\hline & $e$ & $r_{1}$ & $r_{2}$ & $r_{4}$ & $r_{8}$ & $r_{12}$ \\
\hline & $(1)$ & $(2)$ & $(3)$ & $(4)$ & $(5)$ & (6) \\
\hline US Government Surplus-Debt Ratio (\%) & $\begin{array}{l}9.66^{* * *} \\
(1.92)\end{array}$ & $\begin{array}{c}1.31 \\
(0.88)\end{array}$ & $\begin{array}{l}2.58^{* * *} \\
(0.86)\end{array}$ & $\begin{array}{l}5.43^{* * *} \\
(0.90)\end{array}$ & $\begin{array}{l}7.64^{* * *} \\
(2.47)\end{array}$ & $\begin{array}{c}7.21^{*} \\
(4.36)\end{array}$ \\
\hline US Government Debt-GDP Ratio (\%) & $\begin{array}{c}-0.06^{* * *} \\
(0.02)\end{array}$ & $\begin{array}{c}0.01^{*} \\
(0.005)\end{array}$ & $\begin{array}{c}0.01 \\
(0.01)\end{array}$ & $\begin{array}{c}0.03^{* *} \\
(0.01)\end{array}$ & $\begin{array}{l}0.08^{* * *} \\
(0.02)\end{array}$ & $\begin{array}{l}0.13^{* * *} \\
(0.03)\end{array}$ \\
\hline US Treasury Basis (bps) & $\begin{array}{c}-0.05 \\
(0.06)\end{array}$ & $\begin{array}{c}-0.04^{* *} \\
(0.02)\end{array}$ & $\begin{array}{r}-0.04^{*} \\
(0.02)\end{array}$ & $\begin{array}{c}-0.03 \\
(0.04)\end{array}$ & $\begin{array}{c}0.01 \\
(0.05)\end{array}$ & $\begin{array}{l}0.05^{* *} \\
(0.02)\end{array}$ \\
\hline Forward Premium (\%) & $\begin{array}{r}-6.25^{*} \\
(3.35) \\
\end{array}$ & $\begin{array}{c}-0.61 \\
(1.32) \\
\end{array}$ & $\begin{array}{c}-0.35 \\
(1.71) \\
\end{array}$ & $\begin{array}{c}-0.46 \\
(3.29) \\
\end{array}$ & $\begin{array}{c}3.61 \\
(5.63) \\
\end{array}$ & $\begin{array}{c}7.86 \\
(7.02) \\
\end{array}$ \\
\hline Observations & 118 & 118 & 118 & 116 & 112 & 108 \\
\hline $\mathrm{R}^{2}$ & 0.51 & 0.11 & 0.12 & 0.21 & 0.32 & 0.43 \\
\hline $\mathrm{R}^{2}$ without Surplus-Debt Ratio & 0.34 & 0.09 & 0.07 & 0.12 & 0.23 & 0.38 \\
\hline
\end{tabular}

Note: $e$ is the level of dollar index in percentage points; $r_{k}$ is the excess return of the dollar against a basket of foreign currencies in the next $k$ quarters, not annualized and in percentage points. The forward premium and the Treasury basis are included as controls. The constant is not reported. Standard errors are HAC-consistent. ${ }^{*} \mathrm{p}<0.1 ;{ }^{* *} \mathrm{p}<0.05 ;{ }^{* * *} \mathrm{p}<0.01$.

index and returns using total trade weights. (2) Following Stambaugh (1999), I adjust point estimates to account for small-sample bias. (3) Following Lazarus et al. (2018), I use a larger truncation parameter in Newey-West tests to capture long-run covariance. (4) I disaggregate the time series into a panel of 10 foreign countries and run a panel regression. (5) I control for the US current account-to-GDP ratio and for the cyclically-adjusted measure of US imbalance. (6) I use government surplus data from Federal Reserve Economic Data (starting at 1973) and Thomson Reuters International Comparable Economics (starting at 1988). The government surplus-to-debt ratio robustly predicts the dollar's future returns, but it only comoves with the dollar's value in the post-1988 sample.

\section{Comparison with Other Countries}

This fiscal-currency comovement is unique to the US. To repeat this analysis for foreign countries, I fix each foreign country as the home country, and calculate its nominal exchange rate, forward premium and currency return with respect to the equal-weighted basket of 
other countries. Then I regress the home currency's spot exchange rate and future excess return on the home country's government surplus-to-debt ratio and other controls.

Table 2 reports the result. Column (1) shows the benchmark result for the US: A higher US government surplus-to-debt ratio is associated with a stronger dollar and predicts a higher excess return on the dollar in the next 4 quarters. In comparison, higher government surplus-to-debt ratios are not associated with higher nominal exchange rates in 8 out of 10 other developed countries, and do not predict higher currency excess returns in the next 4 quarters in 9 out of 10 other developed countries.

\section{Table 2-Other Countries as the Home Country}

\begin{tabular}{|c|c|c|c|c|c|c|c|c|c|c|}
\hline \multicolumn{11}{|c|}{ Panel A: The dependent variable is each currency's nominal exchange rate e } \\
\hline & $(1)$ & $(2)$ & $(3)$ & $(4)$ & $(5)$ & $(6)$ & $(8)$ & (9) & $(10)$ & $(11)$ \\
\hline & US & Australia & Canada $\mathrm{D}$ & DenmarkC & Germany & Japan & New ZldNorway & Sweden Sw & vitzerland & UK \\
\hline \multirow[t]{2}{*}{ Surplus-Debt Ratio (\%) } & $10.01^{* *}$ & $* *-0.30$ & -1.01 & 0.81 & $-1.14^{* * *}$ & $-12.92^{* * *}$ & $-0.45^{* *}-0.25$ & $3.30^{* * *}$ & 5.32 & $2.83^{* * *}$ \\
\hline & $(1.93)$ & $(0.23)$ & $(0.86)$ & $(0.66)$ & $(0.29)$ & $(4.00)$ & $(0.21) \quad(0.44)$ & $(0.81)$ & $(3.55)$ & $(0.30)$ \\
\hline \multirow[t]{2}{*}{ Debt-GDP Ratio (\%) } & $-0.06^{* *}$ & * $0.09^{* *}$ & $-0.10^{* * *}$ & $*-0.002$ & -0.01 & 0.0001 & $0.22^{*} \quad 0.02$ & 0.02 & -0.19 & $-0.12^{* * *}$ \\
\hline & $(0.02)$ & $(0.04)$ & $(0.02)$ & $(0.04)$ & $(0.03)$ & $(0.02)$ & $(0.11) \quad(0.05)$ & $(0.04)$ & $(0.17)$ & $(0.01)$ \\
\hline \multirow[t]{2}{*}{ Forward Premium (\%) } & -5.94 & $14.44^{* *}$ & -1.04 & $5.44^{* *}$ & 4.08 & 6.80 & $20.80^{* * *} 3.40$ & $26.24^{* * *}$ & -1.89 & $6.19^{* *}$ \\
\hline & $(3.92)$ & $(6.35)$ & $(4.90)$ & $(2.63)$ & $(4.10)$ & $(9.65)$ & $(4.70) \quad(2.32)$ & $(6.58)$ & $(10.44)$ & $(2.43)$ \\
\hline \multirow{3}{*}{$\begin{array}{l}\text { Obser } \\
\mathrm{R}^{2} \\
\end{array}$} & 112 & 112 & 112 & 112 & 112 & 112 & 112 & 112 & 112 & 112 \\
\hline & 0.49 & 0.34 & 0.35 & 0.18 & 0.16 & 0.43 & 0.04 & 0.53 & 0.38 & 0.82 \\
\hline & $P \operatorname{con} t$ & nel B: Tr & penden & nt varic & s eac & curtenc & excess return & $n$ & 4 quart & $T_{4}$ \\
\hline \multirow[t]{2}{*}{ Surplus-Debt Ratio (\%) } & $5.84^{* *}$ & $* *-0.42^{*}$ & $1.53^{*}$ & 1.09 & $0.85^{* *}$ & 2.72 & $-0.39^{* * *} 0.21$ & 0.49 & 0.93 & 0.66 \\
\hline & $(0.95)$ & $(0.23)$ & $(0.78)$ & $(1.01)$ & $(0.39)$ & $(3.89)$ & $(0.13) \quad(0.29)$ & $(1.28)$ & $(0.98)$ & $(0.50)$ \\
\hline \multirow[t]{2}{*}{ Debt-GDP Ratio (\%) } & $0.03^{*}$ & $-0.05^{*}$ & 0.01 & 0.02 & $-0.04^{*}$ & -0.01 & $-0.0003-0.01$ & 0.01 & 0.02 & 0.01 \\
\hline & $(0.01)$ & $(0.03)$ & $(0.02)$ & $(0.03)$ & $(0.02)$ & $(0.01)$ & $(0.04) \quad(0.02)$ & $(0.03)$ & $(0.03)$ & $(0.02)$ \\
\hline \multirow[t]{2}{*}{ Forward Premium (\%) } & -1.09 & $4.09^{*}$ & $6.22^{*}$ & 1.73 & $6.17^{*}$ & 3.06 & $1.16 \quad 0.13$ & 1.04 & $17.13^{* * *}$ & 4.62 \\
\hline & $(3.49)$ & $(2.14)$ & $(3.70)$ & $(1.23)$ & $(3.58)$ & $(7.65)$ & $(2.17) \quad(2.24)$ & $(3.28)$ & $(5.10)$ & $(5.03)$ \\
\hline Observations & 109 & 109 & 109 & 109 & 109 & 109 & 109 & 109 & 109 & 109 \\
\hline $\mathrm{R}^{2}$ & 0.20 & 0.12 & 0.10 & 0.06 & 0.18 & 0.06 & 0.02 & 0.005 & 0.27 & 0.06 \\
\hline
\end{tabular}

Note: I rotate the home country in each column. The explanatory variables are the home country's government surplus-to-debt ratio and government debt-to-GDP ratio, and its average forward premia against the equal-weighted basket of other currencies. Data start at 1990Q1 so that all countries have the same sample period. The constant is not reported. Standard errors are HAC-consistent. ${ }^{*} \mathrm{p}<0.1 ;{ }^{* *} \mathrm{p}<0.05 ;{ }^{* * *} \mathrm{p}<0.01$. 


\section{Impulse Response Functions}

Let us return to the analysis of the US. I evaluate the joint dynamics of the US fiscal condition and the dollar in a first-order vector autoregression (VAR) system:

$$
x_{t+1}=A+B x_{t}+\varepsilon_{t+1},
$$

where the vector $x_{t}$ contains four variables: the US government surplus-to-debt ratio, the US government debt-to-GDP ratio, the US Treasury basis, and the dollar index. The VAR shocks are identified from the Cholesky decomposition: The shock to each variable does not affect the variables that are ordered before it.

Figure 2 reports the impulse responses. Panel (a) shows the responses to a one-standard deviation increase in the US government surplus-to-debt ratio. When this shock arrives, the US dollar immediately appreciates by $0.6 \%$, and continues to appreciate against other currencies in the next 10 quarters, culminating in an appreciation of 2.0\%. Afterwards, the US dollar gradually depreciates back to its original level. This VAR system provides another way to confirm the return predictability of the US government surplus-to-debt ratio without relying on the predictive regressions of overlapping returns.

Moreover, as the US fiscal cycle is persistent, the $0.2 \%$ increase in the government surplusto-debt ratio leads to a $2.0 \%$ increase in the sum of expected future government surplusto-debt ratios. The persistent increase in future government surpluses sets off a sustained reduction in the supply of US government debt. As investors have a downward-sloping demand for the US government debt, the sustained reduction in the supply of US government debt raises the safe asset premium, leading to a more negative Treasury basis. Because a more negative Treasury basis predicts a lower return on the dollar (Jiang, Krishnamurthy and Lustig (2018)), this effect makes the dollar's higher expected return even more puzzling.

Panel (c) shows the responses to a one-standard deviation shock to the US Treasury basis. A higher Treasury basis means a lower convenience yield on the US Treasury, which leads 
Figure 2. Impulse Responses.
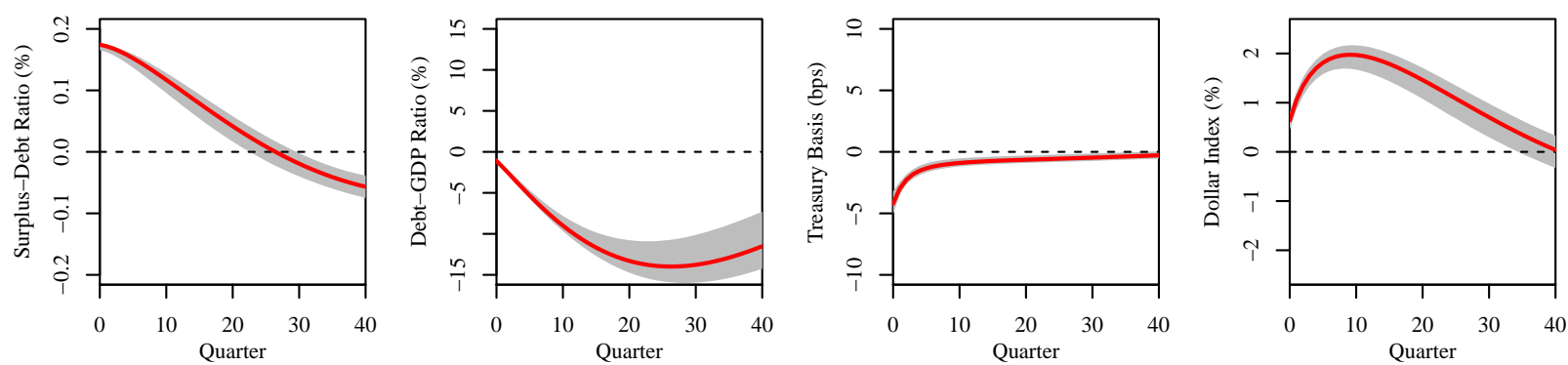

(a) Impulse Responses to a Government Surplus-to-Debt Shock.
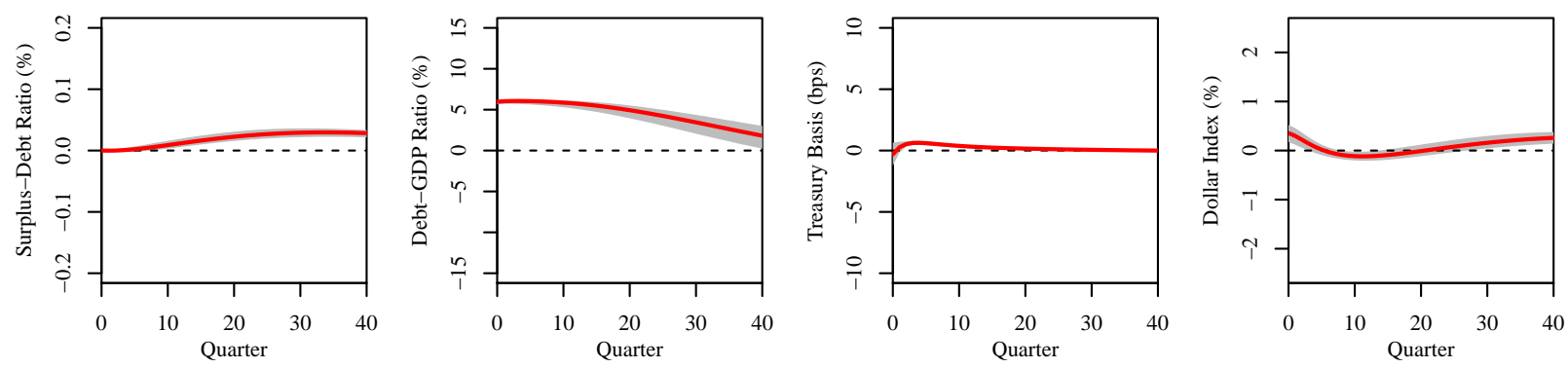

(b) Impulse Responses to a Government Debt-to-GDP Shock.
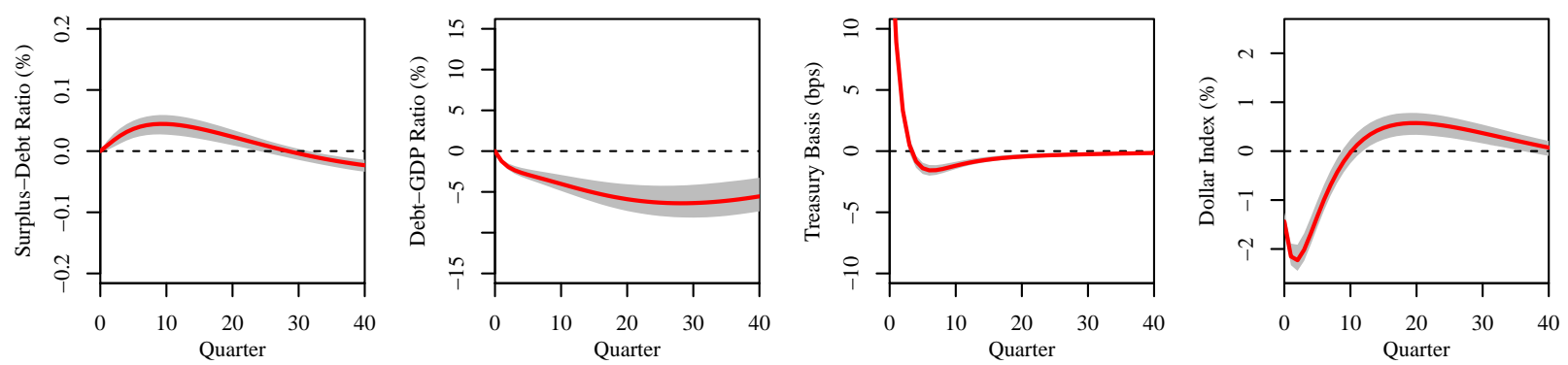

(c) Impulse Responses to a Treasury Basis Shock.
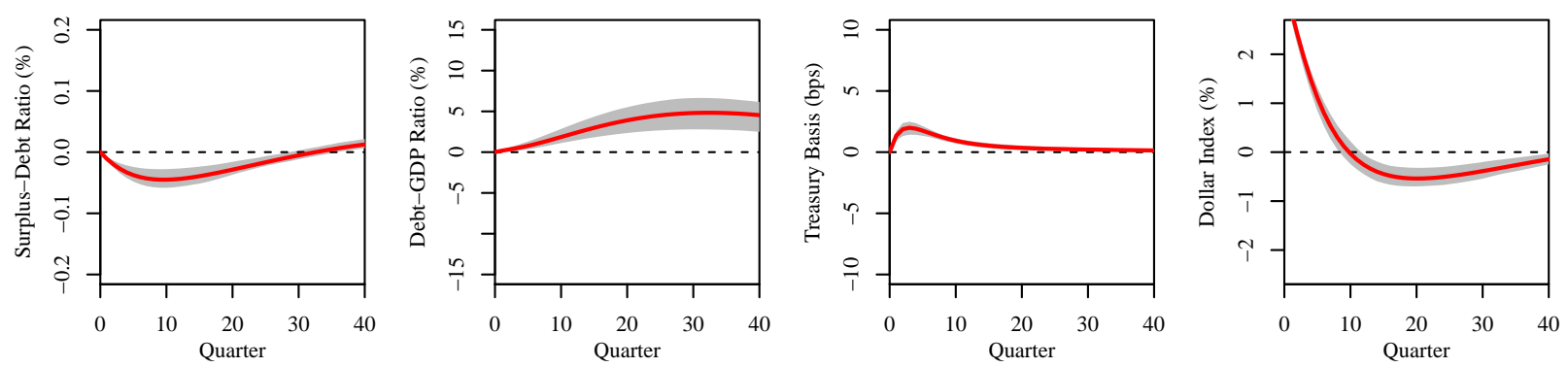

(d) Impulse Responses to a Cumulative Dollar Return Shock.

Note: This panel plots the impulse responses to one-standard-deviation shocks. The VAR system contains the US government surplus-to-debt ratio, the US government debt-to-GDP ratio, the US Treasury basis, and the dollar index. The grey area is the $95 \%$ confidence interval, obtained from 10,000 rounds of simulation. 
to an immediate depreciation of the dollar but predicts dollar appreciation in the next 15 quarters. This effect is in line with the asset pricing intuition that a lower discount rate raises the asset price but lowers future returns. In contrast, the pattern in Panel (a) requires a different explanation.

The response in the US government surplus-to-debt ratio in Panel (a) is more persistent than the response in the US Treasury basis in Panel (c). The fiscal shock also sets off an expected response in the dollar index that lasts longer. The fiscal cycle and the safe asset demand affect the dollar's expected returns at different frequencies.

\section{E. Variance Decomposition of the Dollar Index}

The VAR system also allows me to decompose the forecast error variance of the dollar index. Figure 3 shows the fractions of the unexpected exchange rate movements of the dollar explained by the four variables. In the short run, $82 \%$ of the dollar index's variation is not explained by the shocks to the US government surplus-to-debt ratio, the US government debt-to-GDP ratio, and the US Treasury basis. Of the remaining $18 \%$ of the variation, the US Treasury basis explains $14 \%$.

Figure 3. Variance Decomposition.

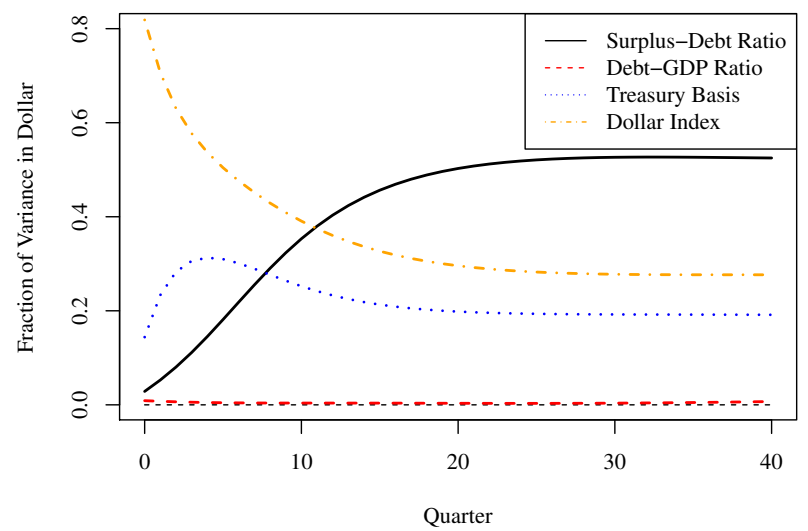

Note: This panel plots the variance of forecast error due to each orthogonalized shock, as implied from the VAR system. 
In the long run, the fraction of variation explained by the US government surplus-to-debt ratio increases to about 50\%, while the fraction explained by US Treasury basis falls back to $20 \%$. This result suggests that the US fiscal cycle and the safe asset premium also affect the dollar's spot exchange rate at different frequencies: The safe asset demand, proxied by the Treasury basis, is quickly mean-reverting. Consistent with the estimation results in Jiang, Krishnamurthy and Lustig (2018), it affects the quarter-to-quarter and the yearto-year variation in the dollar index. The US fiscal cycle, proxied by the US government surplus-to-debt ratio, is slow-moving with an autocorrelation of more than 0.95. It affects the value of the US dollar at the frequency of multiple years.

The impulse responses and the variance decomposition are not sensitive to the ordering of the variables in the VAR system, as reported by the Appendix. The only difference is that any shocks ordered after the dollar index shock no longer affects the spot exchange rate by definition. Even in this case, a shock to the US government surplus-to-debt ratio still predicts the dollar's future exchange rate movements.

\section{Model}

\section{A. The Framework}

The following framework helps us organize these empirical patterns. Consider a model with two countries, US and foreign. Let $m_{t+1}$ denote the US investors' log real pricing kernel, let $q_{t}$ denote the log real exchange rate of the dollar, and let $r_{t}$ and $r_{t}^{*}$ denote the US and foreign log real interest rates. A higher $q_{t}$ means a stronger dollar. The real excess return of the dollar in foreign currency terms is

$$
\exp \left(r x_{t+1}^{\$}\right) \stackrel{\text { def }}{=} \underset{14}{\exp \left(r_{t}-r_{t}^{*}+\Delta q_{t+1}\right) .}
$$


The US investors have the following Euler equations:

$$
\begin{aligned}
\mathbb{E}_{t}\left[\exp \left(m_{t+1}+r_{t}\right)\right] & =1, \\
\mathbb{E}_{t}\left[\exp \left(m_{t+1}+r_{t}^{*}-\Delta q_{t+1}\right)\right] & =1,
\end{aligned}
$$

which, under joint normality of $\left(m_{t+1}, \Delta q_{t+1}\right)$, imply that the expected real excess return of the dollar depends on the covariance between the US pricing kernel $m_{t+1}$ and the foreign currency's appreciation $-\Delta q_{t+1}$ :

$$
\mathbb{E}_{t}\left[r x_{t+1}^{\$}\right] \stackrel{\text { def }}{=} \mathbb{E}_{t}\left[\Delta q_{t+1}+r_{t}-r_{t}^{*}\right]=\operatorname{cov}_{t}\left(m_{t+1},-\Delta q_{t+1}\right)+\frac{1}{2} \operatorname{var}_{t}\left(\Delta q_{t+1}\right) .
$$

When this covariance is negative, the foreign currency depreciates when the US investors' marginal utility is high. In this case, the US investors require a higher risk premium to hold the foreign currency, leading to a lower expected excess return of the dollar.

In the full model, the real exchange rate will be stationary with an unconditional mean of $\lim _{k \rightarrow \infty} \mathbb{E}_{t}\left[q_{t+k}\right]=\bar{q}$. I iterate Eq. (1) forward to express the dollar's real exchange rate as the sum of expected real interest rate differentials minus the sum of expected dollar risk premia (Froot and Ramadorai (2005)):

$$
\begin{aligned}
q_{t} & =\sum_{k=0}^{\infty} \mathbb{E}_{t}\left[r_{t+k}-r_{t+k}^{*}\right] \\
& -\sum_{k=0}^{\infty} \mathbb{E}_{t}\left[\operatorname{cov}_{t+k}\left(m_{t+k+1},-\Delta q_{t+k+1}\right)+\frac{1}{2} \operatorname{var}_{t+k}\left(\Delta q_{t+k+1}\right)\right]+\bar{q}
\end{aligned}
$$

This equation decomposes the exchange rate in a way similar to the Campbell and Shiller (1988) decomposition for stock prices: The real interest rate differentials can be regarded as the cash flows of the dollar, and the dollar risk premia can be regarded as the discount rates. The dollar appreciates when it has higher cash flows or lower discount rates. 


\section{B. Key Mechanisms}

As a stronger US fiscal condition is simultaneously associated with a stronger dollar and a higher expected return on the dollar, the cash flows and the discount rates of the dollar in Eq. (2) need to be positively correlated. This relationship can be generated by the following mechanisms.

On the one hand, the fiscal theory of the price level shows that a currency is priced as the real present value of government surpluses divided by the nominal quantity of government debt:

$$
\frac{1}{P_{t}}=\frac{1}{B_{t-1}} \mathbb{E}_{t}\left[\sum_{j=0}^{\infty}\left(\prod_{k=1}^{j} m_{t+k}\right) s_{t+j}\right]
$$

where $P_{t}$ is the US price level, $B_{t-1}$ is the nominal quantity of US government debt, and $s_{t}$ is the real government surplus of the US. Fixing $B_{t-1}$ and $m_{t+k}$, higher government surpluses $s_{t+j}$ lead to a lower price level $P_{t}$ and therefore a higher nominal value of the dollar.

When prices are sticky, the price level $P_{t}$ does not respond enough to an increase in government surpluses. To equilibrate this equation, the US pricing kernel $m_{t+1}$ must discount the government surpluses at a higher rate. Suppose the risk premium of government surpluses stay the same. Then, the real interest rate $r_{t}$ will rise, and increase the dollar's real exchange rate $q_{t}$ through Eq. (2).

On the other hand, higher government surpluses indicate US expansions. Let $m_{t+1}^{*}$ denote the foreign real pricing kernel. Lustig, Roussanov and Verdelhan (2014) show that if markets are complete, the dollar's real risk premium can also be expressed as

$$
\mathbb{E}_{t}\left[r x_{t+1}^{\$}\right]=\frac{1}{2} \operatorname{var}_{t}\left(m_{t+1}^{*}\right)-\frac{1}{2} \operatorname{var}_{t}\left(m_{t+1}\right)
$$

In a large class of consumption-based asset pricing models, the US pricing kernel $m_{t+1}$ is less volatile during expansions. As the US investors require a lower compensation for holding 
the foreign currency, the dollar will have a higher expected excess return $\mathbb{E}_{t}\left[r x_{t+1}^{\$}\right]$.

In summary, the key assumption is that US government surpluses are higher and the US pricing kernel is less volatile during expansions. Higher US government surpluses increase the dollar's cash flows, leading to a stronger dollar. A less volatile pricing kernel increases the dollar's risk premium, leading to a higher expected return of the dollar.

For parsimony, I set the US real government surplus and the variance of the US pricing kernel to be linear in the US output $x_{t}$ :

$$
\begin{aligned}
s_{t} & =\theta x_{t}, \\
\frac{1}{2} \operatorname{var}_{t}\left(m_{t+1}\right) & =\bar{v}-\gamma x_{t},
\end{aligned}
$$

where the coefficients $\theta$ and $\gamma$ are positive.

\section{A Full Model with Sticky Prices}

Let $x_{t}$ denote the US output, $\pi_{t}$ denote the US inflation, and $b_{t}$ denote the real quantity of US government debt, which is the nominal quantity divided by the price level. The textbook new-Keynesian sticky-price model (Gali and Monacelli (2005); Cochrane (2017)) contains an IS curve, a Fisher equation and a new-Keynesian Phillips curve:

$$
\begin{aligned}
x_{t} & =\mathbb{E}_{t}\left[x_{t+1}\right]-\sigma r_{t}+\varepsilon_{t}, \\
r_{t} & =i_{t}-\mathbb{E}_{t}\left[\pi_{t+1}\right], \\
\pi_{t} & =\beta \mathbb{E}_{t}\left[\pi_{t+1}\right]+\kappa x_{t},
\end{aligned}
$$

where the output shifter $\varepsilon_{t}$ follows an $\operatorname{AR}(1)$ process with an i.i.d. normal shock $u_{t}$ :

$$
\varepsilon_{t}=\zeta \varepsilon_{t-1}+\omega u_{t} .
$$


The full model also contains the decomposition equation of the real exchange rate Eq. (2) and the government budget condition Eq. (3) expressed in the linearized flow form:

$$
b_{t-1}-\pi_{t}=s_{t}+\beta\left(b_{t}-i_{t}\right)
$$

This linearization is derived in Cochrane (2018a). The left-hand side is the real quantity of debt the US government has to pay back in quarter $t$. The right-hand side provides two sources of funding: government surplus $s_{t}$ and the proceeds of the issuance of new debt $\beta\left(b_{t}-i_{t}\right)$.

For simplicity, I set the foreign nominal and real interest rates to be zero, $i_{t}^{*}=r_{t}^{*}=0$, the variance of the foreign pricing kernel to be a constant, $\operatorname{var}\left(m_{t}^{*}\right)=\bar{v}$, and the US nominal interest rate to follow a Taylor rule with no policy shock:

$$
i_{t}=\bar{i}+\phi \pi_{t}+\psi x_{t}
$$

\section{Impulse Responses}

Figure 4 shows the impulse responses to a $0.25 \%$ output shock $u_{1}$. This shock leads to a higher output $x_{t}$ in the next 10 quarters. By assumption, a higher output $x_{t}$ raises the US real government surplus $s_{t}$ of the US and the dollar's risk premium.

In the short run, since prices are sticky, higher government surpluses $s_{t}$ increase the dollar's real interest rates $r_{t+k}$ through Eq. (3). The higher real interest rate immediately raises the dollar's real exchange rate through Eq. (2). At the same time, as the dollar has a higher risk premium, it continues to appreciate in the next 10 quarters.

In the long run, the responses in real interest rates and currency risk premia dissipate. By Eq. (2), the dollar's real exchange rate $q_{t}$ will revert back to its steady-state level. On top of this effect, the real interest rate $r_{t}$ is still above its steady-state value when the output $x_{t}$ falls back to its steady-state value. Through the IS curve Eq. (5), the higher real interest 


\section{Figure 4. Impulse Responses to a Persistent Output Shock in the Model.}
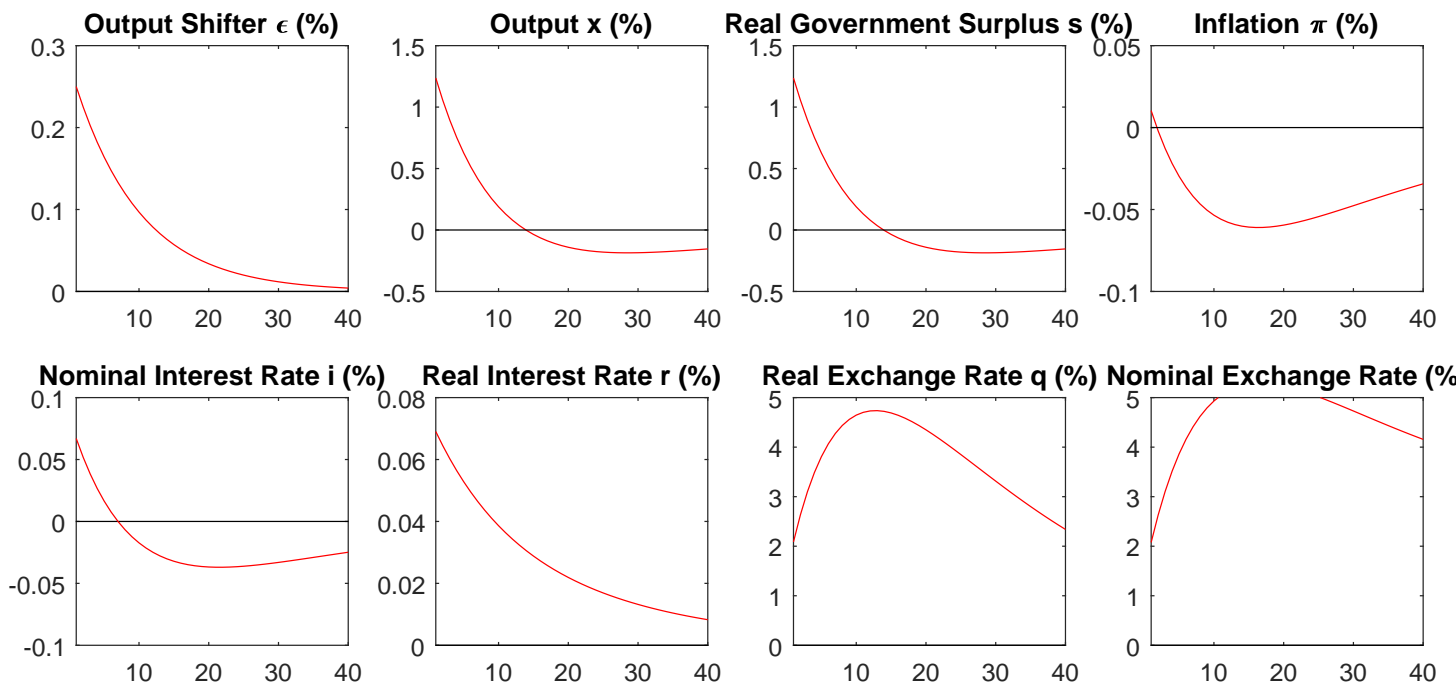

Note: This panel plots the impulse responses to a $0.25 \%$ output shock $u_{1}$. All responses are in percentage points.

rate $r_{t}$ forces the output $x_{t}$ to fall below its steady-state value. As the lower output $x_{t}$ raises the risk premium of the foreign currency, the dollar will have a lower expected return in the long run. The next subsection tests this prediction.

Appendix A discusses the parameter values I use to calibrate this model. In particular, the parameter values imply that firms reset their prices once every 13.5 quarters ${ }^{4}$. This high level of price stickiness has two effects: First, it allows the output shock to have a persistent effect on output. Because the currency risk premium comoves with the output, the dollar will continue to appreciate in the next 10 quarters. Second, it induces the real and the nominal exchange rates to comove. Both effects are absent if prices are not sticky enough, as shown in Figure A1.

${ }^{4}$ Prices in this model are about 3 times as sticky as estimated by Kehoe and Midrigan (2015). Alternatively, if agents have persistent risk premia such as in the habit model or the long-run risk model, the currency risk premium can be persistent with less sticky prices. 


\section{E. Further Implications}

The comovement between the US fiscal cycle and the US investors' risk premium has broader implications. Simulated moments from this model show that the US fiscal cycle also explains other asset pricing patterns including the forward premium puzzle, the term premium, the dollar carry trade, and currency return momentum. Since this model abstracts away from other shocks and mechanisms that affect economic conditions and asset prices, it does not exactly match the empirical moments. Nevertheless, these implications are qualitatively supported by the data.

\section{Forward Premium Puzzle:}

The valuation equation Eq. (8) for government surpluses relates the US fiscal cycle to the real interest rate. As shown in the first row in Panel A of Table 3, this model generates a positive association between the US surplus-to-debt ratio $s / B$ and the US forward premium $f p$.

Since the fiscal cycle also comoves with the dollar's risk premium, this model replicates the forward premium puzzle (Fama (1984)). The second row in Panel A reports the result of the following regression:

$$
r_{t, 1}=a+b \cdot f p_{t}+\varepsilon_{t}
$$

where $r_{t, 1}$ is the excess return of the dollar in the next quarter. Since $b$ is positive, a higher US forward premium predicts a higher excess return on the dollar in the next quarter.

In addition, Engel (2016) finds that a higher US forward premium predicts a lower excess return of the dollar in the long run. As discussed in the previous subsection, this model also generates this effect because the US output eventually overshoots in the opposite direction and induces a negative autocorrelation in the dollar's risk premium. The third row in Panel 
Table 3-Simulated and Data Moments.

\begin{tabular}{|c|c|c|c|c|c|}
\hline \multicolumn{2}{|c|}{ Coefficient } & \multicolumn{2}{|c|}{ Model } & \multicolumn{2}{|c|}{ Data } \\
\hline \multicolumn{6}{|c|}{ Panel A: Forward Premium Puzzle } \\
\hline$f p=a+b \cdot s / B+\varepsilon$ & $b$ & 0.05 & $(0.01)$ & 0.43 & $(0.14)$ \\
\hline$r_{1}=a+b \cdot f p+\varepsilon$ & $b$ & 4.45 & $(1.13)$ & 8.04 & $(4.54)$ \\
\hline$\frac{1}{12}\left(r_{24}-r_{12}\right)=a+b \cdot f p+\varepsilon$ & $b$ & -3.06 & $(1.91)$ & -0.82 & $(0.48)$ \\
\hline \multicolumn{6}{|c|}{ Panel B: Bond Risk Premia } \\
\hline$t p=a+b \cdot s / B+\varepsilon$ & $b$ & -1.26 & $(0.04)$ & -0.63 & $(0.10)$ \\
\hline \multicolumn{6}{|c|}{ Panel C: Dollar Carry Trade } \\
\hline$S R\left(r^{\text {DollarCarry }}\right)$ & - & 0.18 & $(0.09)$ & 0.24 & $(0.09)$ \\
\hline$S R\left(r^{\text {DollarFiscal }}\right)$ & - & 0.29 & $(0.12)$ & 0.27 & $(0.09)$ \\
\hline \multicolumn{6}{|c|}{ Panel D: Currency Return Momentum } \\
\hline \multirow[t]{2}{*}{$r_{1}=a+b \cdot q+c \cdot r_{4}^{p a s t}+\varepsilon$} & $b$ & -0.03 & $(0.02)$ & -0.08 & $(0.03)$ \\
\hline & $c$ & 0.65 & $(0.14)$ & 0.30 & $(0.16)$ \\
\hline \multirow[t]{3}{*}{$r_{1}=a+b \cdot q+c \cdot r_{4}^{p a s t}+d \cdot s / B+\varepsilon$} & $b$ & -0.02 & $(0.02)$ & -0.13 & $(0.03)$ \\
\hline & $c$ & 0.03 & $(0.36)$ & 0.01 & $(0.16)$ \\
\hline & $d$ & 0.47 & $(0.25)$ & 2.41 & $(0.66)$ \\
\hline
\end{tabular}

Note: This table reports the model's moments, averaged from 10,000 rounds of simulations. Each round of simulation generates a sample of 120 quarters. The Sharpe ratios are quarterly. The standard deviations of these moments across simulations are reported in parenthesis. For comparison, the table also reports corresponding data moments. The standard errors of regression coefficients are HAC-consistent, and the standard errors of Sharpe ratios are obtained from bootstrapping.

A confirms this result: The regression equation is

$$
\left(r_{t, 24}-r_{t, 12}\right) / 12=a+b \cdot f p_{t}+\varepsilon_{t}
$$

where the dependent variable is the average quarterly excess return of the dollar between the 13 th quarter and the 24 th quarter in the future. Since $b$ is positive, a higher US forward premium predicts a lower excess return on the dollar in the long run.

\section{Bond Risk Premia:}

Because the US fiscal cycle comoves with the volatility of the US pricing kernel in this model, the US fiscal cycle should also explain the dollar's term premium. When the US fiscal condition is strong, the US investors require a lower compensation to hold the longterm default-free bond in dollar.

Panel B of Table 3 confirms this result: The US term premium $t p$, defined as the annualized yield of the 5-year bond minus that of the 1-year bond, is lower when the US fiscal condition 
is stronger. Appendix C.C2 further shows that the US government surplus-to-debt ratio alone explains $35 \%$ of the variation in the term premium and $37 \%$ in Cochrane and Piazzesi (2005) bond factor.

Lustig, Stathopoulos and Verdelhan (2017) find that the predictability of foreign bond returns decreases as the maturity of the bond increases, and conclude that local currency term premia offset currency risk premia. The US fiscal cycle offers one source of variation that drives opposite movements in currency risk premia and US term premia. In univariate regressions, a $1 \%$ higher US government surplus-to-debt ratio predicts a $6 \%$ higher excess return on the dollar and a 3\% lower excess return on the 5-year US Treasury.

\section{Dollar Carry Trade:}

Lustig, Roussanov and Verdelhan (2014) construct a dollar carry trade that buys foreign currencies against the dollar whenever the US forward premium is below 0, which typically occurs during U.S. recessions, and shorts foreign currencies against the dollar otherwise. This trading strategy produces an annual Sharpe ratio in excess of 0.50 .

Since the US fiscal cycle comoves with the dollar's risk premium, I also construct a dollar fiscal trade that buys foreign currencies against the dollar whenever the US government surplus-to-debt ratio is below its steady-state value, and shorts foreign currencies otherwise.

Panel C of Table 3 shows that both trading strategies have large and positive Sharpe ratios in the model. Appendix C.C3 presents additional empirical tests for robustness. When I control for the dollar fiscal trade's returns, the dollar carry trade does not have statistically significant abnormal returns.

\section{Currency Return Momentum:}

Burnside, Eichenbaum and Rebelo (2011); Moskowitz, Ooi and Pedersen (2012); Asness, Moskowitz and Pedersen (2013) find that currencies that have higher returns in the past year tend to have higher returns in the near future. This finding can be seen from the following 
regression:

$$
r_{t, 1}=a+b \cdot r_{t-4,4}+c \cdot q_{t}+\varepsilon_{t}
$$

where $r_{t, 1}$ is the excess return of the dollar in the next quarter, and $r_{t-4,4}$ is its past excess return from quarter $t-4$ to quarter $t$. Controlling for the exchange rate level $q_{t}$ is important because it is mean-reverting in the long run.

In my model, when the US government's fiscal condition improves, the dollar appreciates and has a higher expected return, leading to a positive correlation between past and future currency returns in the short run. The first two rows in Panel D of Table 3 report the coefficient estimates. Since $c$ is positive, this model generates currency return momentum.

If the US fiscal cycle drives the dollar's return momentum, the coefficient $c$ should vanish when I control for the US government surplus-to-debt ratio in the following regression:

$$
r_{t, 1}=a+b \cdot r_{t-4,4}+c \cdot q_{t}+d \cdot \frac{\mathrm{US} \text { Gov } \text { Surplus }_{t}}{\mathrm{US} \text { Gov Debt }}+\varepsilon_{t-1}
$$

The next three rows in Panel D of Table 3 report the result. In the model and in the data, $c$ is close to 0 while $d$ is positive and significant. The US government surplus-to-debt ratio drives out the forecasting power of the dollar's past returns.

\section{Discussion: What Makes the US Special?}

The data show that the US is exceptional in the comovement between its fiscal condition, currency value and expected currency returns. The model highlights the comovement between the US fiscal cycle and the dollar's risk premium as the key driver. If so, this fiscal-

currency comovement must be unique to the US. In this section, I present further evidence in support of this argument. 


\section{A. Cross-Border Capital Flows}

If the US fiscal cycle comoves with the US investors' risk appetite for foreign currencies, it should also manifest itself in the US investors' investments in other foreign risky assets.

I obtain capital flow data from Bertaut and Tryon (2007); Bertaut and Judson (2014). Let $\operatorname{pos}_{t}^{\text {stock }}$ denote the dollar value of foreign equities held by US investors at the end of quarter $t$. Let $f_{l o w}^{\text {stock }}$ denote the capital flows into foreign stocks from the end of quarter $t$ to the end of quarter $t+k$. The capital flows do not include the changes in the foreign asset positions that are due to changes in asset valuation. Let $\operatorname{pos}_{t}^{\text {bond }}$ and $f l o w_{t, k}^{\text {bond }}$ denote the corresponding variables for the US investors' holdings of foreign bonds. All these variables are normalized by the US GDP in corresponding quarters. I regress current asset positions and future flows on the US government surplus-to-debt ratio and the US government debt-to-GDP ratio:

$$
\operatorname{pos}_{t}^{\text {stock }} \text { or } \text { flow }_{t, k}^{\text {stock }}=\alpha+\beta \frac{\mathrm{US} \mathrm{Gov} \mathrm{Surplus}_{t}}{\mathrm{US} \text { Gov Debt }}+\gamma \frac{\mathrm{US} \mathrm{Gov} \mathrm{Debt}_{t-1}}{\mathrm{US} \mathrm{GDP}_{t}} \varepsilon_{t} .
$$

Table 4 reports the result. A 1\% increase in the US government surplus-to-debt ratio corresponds to $12.68 \%$ higher holdings of foreign stocks as a fraction of the US quarterly GDP during the same quarter, and predicts that the US investors will continue to allocate $0.88 \%$ of their quarterly GDP into foreign stocks in the following 4 quarters.

The capital flows into foreign bonds have a different pattern: A $1 \%$ increase in the US government surplus-to-debt ratio corresponds to $0.50 \%$ higher holdings of foreign bonds as a fraction of the US quarterly GDP, and predicts a $1.56 \%$ reduction of the US quarterly GDP from foreign bonds in the following 4 quarters.

To the extent that the US investors' risk premium affects its capital flows into foreign risky assets $^{5}$, these results also validate the comovement between the US fiscal cycle and the US investors' risk premium. In comparison, as foreign investors mainly hold safe US assets and

\footnotetext{
${ }^{5}$ See Alvarez, Atkeson and Kehoe (2002, 2009); Pavlova and Rigobon (2012); Bruno and Shin (2014); Chien, Lustig and Naknoi (2015); Dou and Verdelhan (2015); Maggiori (2017).
} 


\section{TABle 4-US Flows into Foreign Assets.}

\begin{tabular}{|c|c|c|c|c|c|c|c|c|}
\hline & \multicolumn{8}{|c|}{ Dependent variable: } \\
\hline & $\begin{array}{c}p_{0} s_{t}^{\text {stock }} \\
(1)\end{array}$ & $\begin{array}{c}\text { flow }_{t, 1}^{\text {stock }} \\
(2) \\
\end{array}$ & $\begin{array}{c}\text { flow }_{t, 2}^{\text {stock }} \\
(3) \\
\end{array}$ & $\begin{array}{c}\text { flow }_{t, 4}^{\text {stock }} \\
(4)\end{array}$ & $\begin{array}{c}\operatorname{pos}_{t}^{\text {bond }} \\
(5)\end{array}$ & $\begin{array}{c}\text { flow }_{t, 1}^{\text {bond }} \\
(6) \\
\end{array}$ & $\begin{array}{c}\text { flow }_{t, 2}^{\text {bond }} \\
(7) \\
\end{array}$ & $\begin{array}{c}\text { flow }_{t, 4}^{\text {bond }} \\
(8)\end{array}$ \\
\hline US Government Surplus-Debt Ratio (\%) & $\begin{array}{l}12.68^{* * *} \\
(2.22)\end{array}$ & $\begin{array}{cc}* & 0.26^{* *} \\
& (0.11)\end{array}$ & $\begin{array}{l}0.51^{* * *} \\
(0.16)\end{array}$ & $\begin{array}{l}0.88^{* * *} \\
(0.28)\end{array}$ & $\begin{array}{c}0.50 \\
(0.47)\end{array}$ & $\begin{array}{r}-0.33^{*} \\
(0.17)\end{array}$ & $\begin{array}{c}-0.69^{* * *} \\
(0.27)\end{array}$ & $\begin{array}{c}-1.56^{* * *} \\
(0.55)\end{array}$ \\
\hline US Government Debt-GDP Ratio (\%) & $\begin{array}{c}0.01 \\
(0.08)\end{array}$ & $\begin{array}{c}0.001 \\
(0.001)\end{array}$ & $\begin{array}{c}0.003^{*} \\
(0.001)\end{array}$ & $\begin{array}{r}0.01^{* *} \\
(0.003)\end{array}$ & $\begin{array}{l}0.05^{* * *} \\
(0.01)\end{array}$ & $\begin{array}{c}-0.005^{* *} \\
(0.002)\end{array}$ & $\begin{array}{r}-0.01^{* *} \\
(0.004)\end{array}$ & $\begin{array}{c}-0.02^{* * *} \\
(0.01)\end{array}$ \\
\hline date & $\begin{array}{c}0.02^{* * *} \\
(0.002) \\
\end{array}$ & & & & $\begin{array}{c}0.004^{* * *} \\
(0.0004)\end{array}$ & & & \\
\hline Observations & 91 & 90 & 89 & 87 & 91 & 90 & 89 & 87 \\
\hline $\mathrm{R}^{2}$ & 0.89 & 0.07 & 0.14 & 0.21 & 0.95 & 0.23 & 0.29 & 0.38 \\
\hline
\end{tabular}

Note: Since both the asset positions and the US government debt-to-GDP ratio have strong time trends, I include the date in the regressions of asset positions. Data are quarterly from 1994Q1 to 2016Q4. Standard errors are HAC-consistent. ${ }^{*} \mathrm{p}<0.1 ;{ }^{* *} \mathrm{p}<0.05 ;{ }^{* * *} \mathrm{p}<0.01$.

believe the dollar is safe during global recessions, they do not necessarily demand a higher risk premium to hold the dollar when their risk aversion is high.

\section{B. US Treasury as Reserve Assets}

The fiscal-currency comovement in the US is also related to the role of the US Treasury as the international reserve asset. Farhi and Maggiori (2017) study a model of a hegemon that issues reserve assets. If this hegemon issuer is interpreted as the US government, then a lower US government surplus strains the commitment of the US government to maintaining a strong dollar during global recessions, opening up the possibility of a self-fulfilling crisis in the dollar. This mechanism not only amplifies the connection between the US fiscal cycle and the dollar's value, but also relates the US fiscal cycle to global business cycles and risk appetite.

The sunspot realization in Farhi and Maggiori (2017)'s model is difficult to measure. Nevertheless, I can gauge the confidence in dollar reserve assets from the currency composition in official foreign exchange reserves. I obtain the Currency Composition of Official Foreign Exchange Reserve (COFER) from the IMF. This dataset covers the period from 1995 to 
2018. The data are annual before 1999, and are quarterly since 1999. I regress the US dollar's share in the world's foreign exchange reserves on the US government surplus-to-debt ratio and the US government debt-to-GDP ratio:

$$
\frac{\text { World Reserves in Dollar }_{t}}{\text { Total World Reserves }}+=\alpha+\beta \frac{\text { US Gov Surplus }}{t}+\gamma \frac{\text { US Gov Debt }_{t-1}}{\text { US Gov Debt }_{t-1}} \varepsilon_{t} .
$$

Table 5 presents the result. A $1 \%$ increase in the US government surplus-to-debt ratio is associated with a $2.15 \%$ increase in the dollar's share in the world official reserves. In the time series, the dollar's share has a mean of $65.46 \%$ and a standard deviation of $3.38 \%$. The US fiscal cycle explains a large fraction of its variation: The $R^{2}$ in Column (1) is $67 \%$.

This result is robust after I control for the US Treasury basis and the US dollar's forward premium, although a more negative (wider) US Treasury basis is also associated with more dollar held in the world official reserves.

Columns (3) to (5) repeat the same regression but use other currencies' shares in the world official reserves as the dependent variable. The US fiscal cycle also explains large fractions of variations in their shares: An increase in dollar reserves largely comes from a decline in

Table 5-US Dollar in World Official Foreign Exchange Reserves.

\begin{tabular}{|c|c|c|c|c|c|}
\hline & \multicolumn{5}{|c|}{ Dependent variable: } \\
\hline & \multicolumn{2}{|c|}{ USD } & \multirow{2}{*}{$\begin{array}{c}\text { EUR } \\
(3)\end{array}$} & \multirow{2}{*}{$\begin{array}{c}\text { YEN } \\
(4)\end{array}$} & \multirow{2}{*}{$\begin{array}{c}\text { GBP } \\
(5)\end{array}$} \\
\hline & $(1)$ & $(2)$ & & & \\
\hline US Government Surplus-Debt Ratio (\%) & $\begin{array}{l}2.15^{* * *} \\
(0.34)\end{array}$ & $\begin{array}{l}2.67^{* * *} \\
(0.56)\end{array}$ & $\begin{array}{c}-3.43^{* * *} \\
(0.28)\end{array}$ & $\begin{array}{l}0.74^{* * *} \\
(0.16)\end{array}$ & $\begin{array}{r}-0.18^{*} \\
(0.10)\end{array}$ \\
\hline US Government Debt-GDP Ratio (\%) & $\begin{array}{c}-0.02^{* * *} \\
(0.01)\end{array}$ & $\begin{array}{c}-0.02^{* * *} \\
(0.005)\end{array}$ & $\begin{array}{c}-0.002 \\
(0.005)\end{array}$ & $\begin{array}{c}-0.004^{* *} \\
(0.002)\end{array}$ & $\begin{array}{c}0.004^{* *} \\
(0.002)\end{array}$ \\
\hline US Treasury Basis (bps) & & $\begin{array}{c}-0.03^{* * *} \\
(0.01)\end{array}$ & & & \\
\hline Forward Premium (\%) & & $\begin{array}{r}316.27^{*} \\
(184.21) \\
\end{array}$ & & & \\
\hline Observations & 79 & 78 & 75 & 79 & 79 \\
\hline $\mathrm{R}^{2}$ & 0.67 & 0.71 & 0.70 & 0.53 & 0.37 \\
\hline
\end{tabular}

Note: I regress the fraction of the world official foreign exchange reserves in each currency on the US government surplus-to-debt ratio and other controls. Standard errors are HAC-consistent. ${ }^{*} \mathrm{p}<0.1 ;{ }^{* *} \mathrm{p}<0.05$; ${ }^{* * *} \mathrm{p}<0.01$. 
Euro reserves, whereas Yen reserves also increase when the US government surplus is higher. 


\section{REFERENCES}

Alvarez, Fernando, Andrew Atkeson, and Patrick J Kehoe. 2002. "Money, interest rates, and exchange rates with endogenously segmented markets." Journal of Political Economy, 110(1): 73-112.

Alvarez, Fernando, Andrew Atkeson, and Patrick J Kehoe. 2009. "Time-varying risk, interest rates, and exchange rates in general equilibrium." The Review of Economic Studies, 76(3): 851-878.

Arellano, Manuel. 1987. "Computing Robust Standard Errors for Within-Groups Estimators." Oxford Bulletin of Economics and Statistics, 49(4): 431-34.

Asness, Clifford S, Tobias J Moskowitz, and Lasse Heje Pedersen. 2013. "Value and momentum everywhere." The Journal of Finance, 68(3): 929-985.

Backus, David K, and Gregor W Smith. 1993. "Consumption and real exchange rates in dynamic economies with non-traded goods." Journal of International Economics, 35(34): $297-316$.

Bansal, Ravi, and Ivan Shaliastovich. 2013. "A Long-Run Risks Explanation of Predictability Puzzles in Bond and Currency Markets." Review of Financial Studies, 26(1).

Bénétrix, Agustín S, and Philip R Lane. 2010. "Fiscal shocks and the sectoral composition of output." Open Economies Review, 21(3): 335-350.

Bénétrix, Agustın S, and Philip R Lane. 2011. "Financial Cycles and Fiscal Cycles."

Bertaut, Carol, and Ruth Judson. 2014. "Estimating US Cross-Border Securities Positions: New Data and New Methods."

Bertaut, Carol C, and Ralph W Tryon. 2007. "Monthly Estimates of US Cross-border Securities Positions." 
Bolton, Patrick, and Haizhou Huang. 2017. "The capital structure of nations." Review of Finance.

Bruno, Valentina, and Hyun Song Shin. 2014. "Cross-border banking and global liquidity." The Review of Economic Studies, 82(2): 535-564.

Burnside, Craig, Martin Eichenbaum, and Sergio Rebelo. 2001. "Prospective deficits and the Asian currency crisis." Journal of Political Economy, 109(6): 1155-1197.

Burnside, Craig, Martin Eichenbaum, and Sergio Rebelo. 2003. "On the fiscal implications of twin crises." In Managing currency crises in emerging markets. 187-224. University of Chicago Press.

Burnside, Craig, Martin Eichenbaum, and Sergio Rebelo. 2011. "Carry trade and momentum in currency markets."

Campbell, John Y, and Robert J Shiller. 1988. "The Dividend-Price Ratio and Expectations of Future Dividends and Discount Factors." Review of Financial Studies, 1(3): 195228.

Chien, YiLi, Hanno N Lustig, and Kanda Naknoi. 2015. "Why Are Exchange Rates So Smooth? A Segmented Asset Markets Explanation." FRB St. Louis Working Paper, , (2015-39).

Cochrane, John H. 2001. "Long-Term Debt and Optimal Policy in the Fiscal Theory of the Price Level." Econometrica, 69(1): 69-116.

Cochrane, John H. 2005. "Money as Stock." Journal of Monetary Economics, 52(3): 501528.

Cochrane, John H. 2017. "Michelson-Morley, Occam and Fisher: The Radical Implications of Stable Inflation at Near-Zero Interest Rates." In NBER Macroeconomics Annual 2017, volume 32. University of Chicago Press. 
Cochrane, John H. 2018a. "The Fiscal Theory of the Price Level."

Cochrane, John H. 2018b. "Stepping on a rake: The fiscal theory of monetary policy." European Economic Review, 101: 354-375.

Cochrane, John H, and Monika Piazzesi. 2005. "Bond risk premia." American Economic Review, 95(1): 138-160.

Colacito, Riccardo, and Mariano M Croce. 2011. "Risks for the Long Run and the Real Exchange Rate." Journal of Political Economy, 119(1): 153-181.

Colacito, Riccardo, and Mariano M Croce. 2013. "International asset pricing with recursive preferences." The Journal of Finance, 68(6): 2651-2686.

Colacito, Riccardo, Mariano Massimiliano Croce, Federico Gavazzoni, and Robert C Ready. Forthcoming. "Currency risk factors in a recursive multi-country economy." Journal of Finance.

Corsetti, Giancarlo, and Bartosz Mackowiak. 2001. "Nominal debt and the dynamics of currency crises."

Daniel, Betty C. 2001a. "A fiscal theory of currency crises." International Economic Review, 42(4): 969-988.

Daniel, Betty C. 2001b. "The Fiscal Theory of the Price Level in an Open Economy." Journal of Monetary Economics, 48(2): 293-308.

Dou, Winston Wei, and Adrien Verdelhan. 2015. "The Volatility of International Capital Flows and Foreign Assets." Working Paper MIT Sloan.

Dupor, Bill. 2000. "Exchange Rates and the Fiscal Theory of the Price Level." Journal of Monetary Economics, 45(3): 613-630. 
Du, Wenxin, Joanne Im, and Jesse Schreger. 2018. "The US Treasury Premium." Journal of International Economics, 112: 167-181.

Engel, Charles. 2016. "Exchange rates, interest rates, and the risk premium." American Economic Review, 106(2): 436-74.

Engel, Charles, and Kenneth D West. 2010. "Global interest rates, currency returns, and the real value of the dollar." American Economic Review, 100(2): 562-67.

Evans, Martin DD, and Richard K Lyons. 2002. "Order flow and exchange rate dynamics." Journal of political economy, 110(1): 170-180.

Fama, Eugene F. 1984. "Forward and Spot Exchange Rates." Journal of Monetary Economics, 14(3): 319-338.

Farhi, Emmanuel, and Matteo Maggiori. 2017. "A model of the international monetary system." The Quarterly Journal of Economics, 133(1): 295-355.

Farhi, Emmanuel, and Xavier Gabaix. 2016. "Rare Disasters and Exchange Rates." Quarterly Journal of Economics.

Fourel, Valère, Dagfinn Rime, Lucio Sarno, Maik Schmeling, and Adrien Verdelhan. 2015. "Common Factors, Order Flows, and Exchange Rate Dynamics."

Froot, Kenneth A, and Tarun Ramadorai. 2005. "Currency returns, intrinsic value, and institutional-investor flows." The Journal of Finance, 60(3): 1535-1566.

Gali, Jordi, and Tommaso Monacelli. 2005. "Monetary policy and exchange rate volatility in a small open economy." The Review of Economic Studies, 72(3): 707-734.

Gourinchas, Pierre-Olivier, and Helene Rey. 2007. "International Financial Adjustment." Journal of Political Economy, 115(4). 
Gourinchas, Pierre-Olivier, and Hélène Rey. 2014. "External adjustment, global imbalances, valuation effects." In Handbook of International Economics. Vol. 4, 585-645. Elsevier.

Gourinchas, Pierre-Olivier, Helene Rey, and Maxime Sauzet. 2018. "The International Monetary and Financial System."

Gourinchas, Pierre-Olivier, Helene Rey, Nicolas Govillot, et al. 2010. "Exorbitant privilege and exorbitant duty." Institute for Monetary and Economic Studies, Bank of Japan.

Gourio, Francois, Michael Siemer, and Adrien Verdelhan. 2013. "International risk cycles." Journal of International Economics, 89(2): 471-484.

Hassan, Tarek A. 2013. "Country size, currency unions, and international asset returns." The Journal of Finance, 68(6): 2269-2308.

Hau, Harald, and Hélène Rey. 2004. "Can portfolio rebalancing explain the dynamics of equity returns, equity flows, and exchange rates?" American Economic Review, 94(2): 126133.

Hau, Harald, and Helene Rey. 2005. "Exchange rates, equity prices, and capital flows." The Review of Financial Studies, 19(1): 273-317.

Heyerdahl-Larsen, Christian. 2014. "Asset prices and real exchange rates with deep habits." Review of Financial Studies, 27(11): 3280-3317.

He, Zhiguo, Arvind Krishnamurthy, and Konstantin Milbradt. 2019. "A model of safe asset determination." American Economic Review.

Jiang, Zhengyang, Arvind Krishnamurthy, and Hanno Lustig. 2019. "Dollar Safety and the Global Financial Cycle." 
Jiang, Zhengyang, Arvind Krishnamurthy, and Hanno N Lustig. 2018. "Foreign Safe Asset Demand and the Dollar Exchange Rate."

Kehoe, Patrick, and Virgiliu Midrigan. 2015. "Prices are sticky after all." Journal of Monetary Economics, 75: 35-53.

Lazarus, Eben, Daniel J Lewis, James H Stock, and Mark W Watson. 2018. "HAR Inference: Recommendations for Practice." Journal of Business 83 Economic Statistics, 36(4): 541-559.

Leeper, Eric M. 1991. "Equilibria under Active and Passive Monetary and Fiscal Policies." Journal of monetary Economics, 27(1): 129-147.

Liu, Yang. 2016. "Government debt and risk premia."

Lustig, Hanno, and Adrien Verdelhan. 2015. "Does Market Incompleteness Help to Explain Exchange Rates? A Quantitative Assessment."

Lustig, Hanno, Andreas Stathopoulos, and Adrien Verdelhan. 2017. "The Term Structure of Currency Carry Trade Risk Premia."

Lustig, Hanno, Nikolai Roussanov, and Adrien Verdelhan. 2014. "Countercyclical currency risk premia." Journal of Financial Economics, 111(3): 527-553.

Maggiori, Matteo. 2017. "Financial intermediation, international risk sharing, and reserve currencies." American Economic Review, 107(10): 3038-71.

Maggiori, Matteo, Brent Neiman, and Jesse Schreger. 2018. "International currencies and capital allocation." National Bureau of Economic Research.

Martin, Ian. 2013. "The forward premium puzzle in a two-country world."

Meese, Richard A, and Kenneth Rogoff. 1983. "Empirical exchange rate models of the seventies: Do they fit out of sample?" Journal of international economics, 14(1-2): 3-24. 
Moskowitz, Tobias J, Yao Hua Ooi, and Lasse Heje Pedersen. 2012. "Time series momentum." Journal of financial economics, 104(2): 228-250.

Nguyen, Thien Tung. 2018. "Fiscal risk and bond yields predictability."

Obstfeld, Maurice, and Kenneth Rogoff. 2000. "The six major puzzles in international macroeconomics: is there a common cause?" NBER macroeconomics annual, 15: 339-390.

Pavlova, Anna, and Roberto Rigobon. 2012. "Equilibrium portfolios and external adjustment under incomplete markets."

Richmond, Robert J. 2016. "Trade network centrality and currency risk premia."

Sargent, Thomas J, and Neil Wallace. 1984. "Some Unpleasant Monetarist Arithmetic." In Monetarism in the United Kingdom. 15-41. Springer.

Sims, Christopher A. 1994. "A Simple Model for Study of the Determination of the Price Level and the Interaction of Monetary and Fiscal Policy." Economic Theory, 4(3): 381-99.

Stambaugh, Robert F. 1999. "Predictive regressions." Journal of Financial Economics, 54(3): 375-421.

Stathopoulos, Andreas. 2016. "Asset Prices and Risk Sharing in Open Economies." The Review of Financial Studies, 30(2): 363-415.

Valchev, Rosen. 2017. "Bond convenience yields and exchange rate dynamics."

Verdelhan, Adrien. 2010. "A Habit-Based Explanation of the Exchange Rate Risk Premium." The Journal of Finance, 65(1): 123-146.

Woodford, Michael. 1994. "Monetary Policy and Price Level Determinacy in a Cash-inAdvance Economy." Economic Theory, 345-380. 


\section{Appendix A: Model}

\section{A1. Calibration}

Table A1 shows the parameter values used in calibration. The model is calibrated at the quarterly frequency. The real discount rate $\beta$ is 0.99 , implying a real discount rate of $1 \%$ per quarter at the steady state. The parameter $\sigma$ in the IS curve is 1 , which is consistent with the elasticity of intertemporal substitution as implied by a log utility.

The parameter $\kappa$ governing price stickiness is 0.01 . In the textbook new-Keynesian model with the production technology linear in labor, this parameter is a function of the frequency of price reset $\phi$, discount rate $\beta$, and the steady-state labor input $\bar{n}$ :

$$
\kappa \equiv \frac{(1-\phi)(1-\phi \beta)}{\phi} \frac{1}{1-\bar{n}}
$$

When $\beta=0.99$ and $\bar{n}=1 / 3$, this parameter value implies $\phi=0.9259$. That is, $92.6 \%$ of the firms do not reset their prices in each quarter, or firms reset their prices once every 13.5 quarters.

When the output shock is $1 \%$, the government surplus rises by $\theta \times 1 \%=1 \%$ and the risk premium of the foreign currency goes down by $-\gamma \times 1 \%=-0.5 \%$. These parameters are set so that the real exchange rate movement is 1.25 times as volatile as the growth rate of output. In the data the real exchange rate movement is about 4 times as volatile, but the real exchange rate is also driven by other shocks.

The output shock $u_{t}$ has an autocorrelation of $\rho=0.9$. This parameter is set so that a positive output shock increases output for 10 quarters (2 and half years).

The US nominal interest rate follows a Taylor rule, reproduced below:

$$
i_{t}=\bar{i}+\phi \pi_{t}+\psi x_{t}
$$

The US nominal interest rate is higher when inflatoin $\pi_{t}$ is higher and when output $x_{t}$ is higher. A positive $\psi$ is

TABle A1-Parameter Values.

\begin{tabular}{l|c|c}
\hline \hline Parameter & Notation & Value \\
\hline \hline Real Discount Rate & $\beta$ & 0.99 \\
Elasticity of Intertemporal Substitution & $\sigma$ & 1 \\
Price Stickiness & $\kappa$ & 0.01 \\
Cyclicality of Government Surplus & $\theta$ & 1 \\
Cyclicality of Currency Risk Premium & $\gamma$ & 0.5 \\
Persistence of Output Shock & $\rho$ & 0.9 \\
Taylor Rule Coefficient for Inflation & $\phi$ & 0.5 \\
Taylor Rule Coefficient for Output & $\psi$ & 0.05 \\
\hline \hline
\end{tabular}


needed to generate comovement in real and nominal interest rates in this simple model.

\section{A2. When prices are not sticky}

Figure A1 shows the impulse responses when the prices are not sticky. Although the shock $\varepsilon_{t}$ is persistent, the real interest rate adjusts so the response in output is not persistent. The dollar does not continue to appreciate after the output shock, and the nominal and the real exchange rates do not comove.

Figure A1. Impulse Responses to a Persistent Output Shock in the Model, $\kappa=99$.
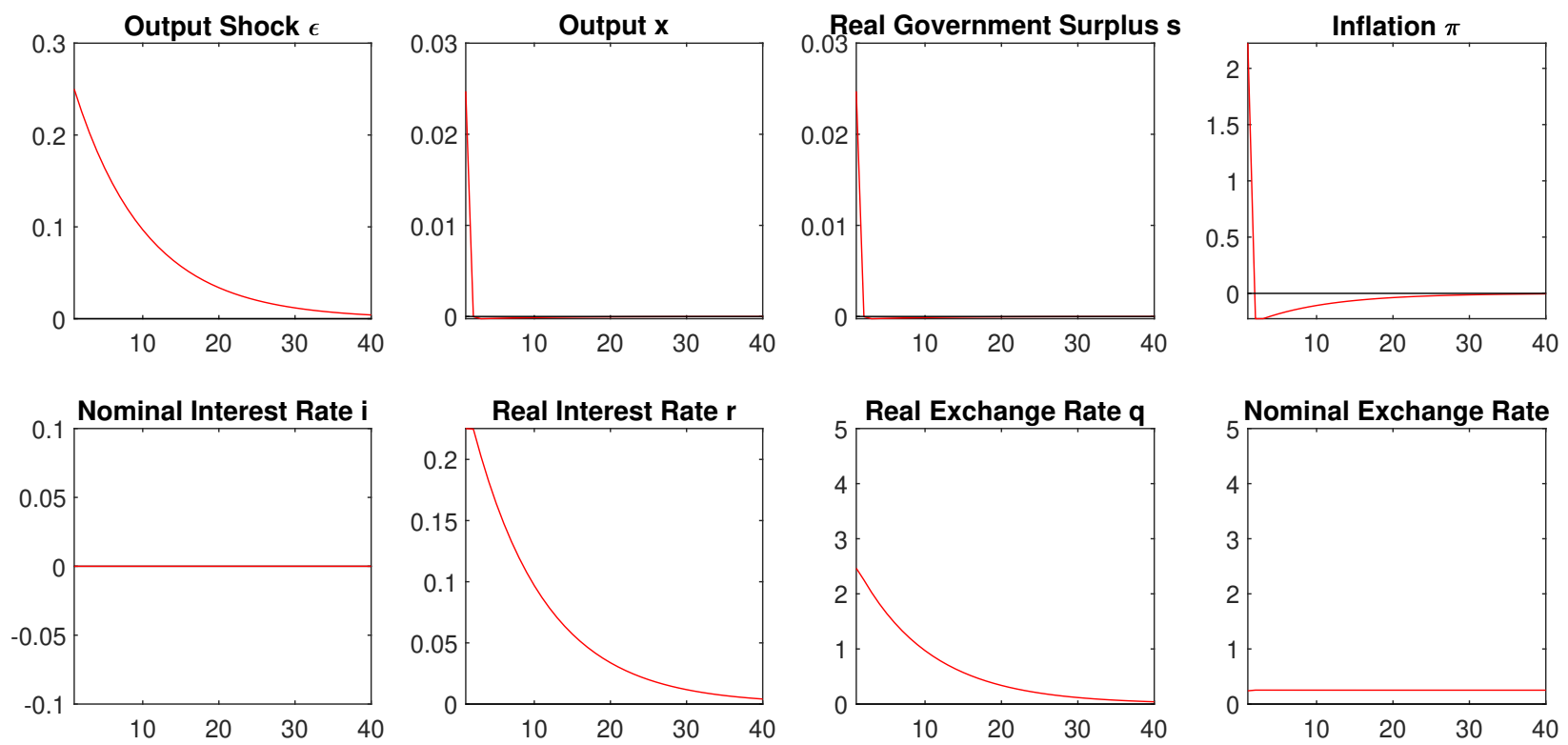

Note: This panel plots the impulse responses to a $0.25 \%$ output shock $u_{1}$. The price stickiness parameter $\kappa$ is 99 , implying $98.5 \%$ of the firms reset their prices every quarter. All responses are in percentage points.

\section{A3. Derivation of Term Structure}

The linearized system can be expressed as a vector autoregressive process:

$$
z_{t}=\Psi z_{t-1}+\Gamma u_{t}
$$

Let $e_{x}$ be the vector of zeros except the row corresponding to output in $z_{t}$, and let $e_{r}$ be the vector of zeros except 
the row corresponding to the real interest rate. Then $e_{x}^{\prime} z_{t}=x_{t}$ and $\bar{r}+e_{r}^{\prime} z_{t}=r_{t}$. Then

$$
\begin{aligned}
\frac{1}{2} \operatorname{var}_{t}\left(m_{t+1}\right) & =\bar{v}-\gamma e_{x}^{\prime} z_{t} \\
-\bar{r}-e_{r}^{\prime} z_{t} & =\mathbb{E}_{t}\left[m_{t+1}\right]+\frac{1}{2} \operatorname{var}_{t}\left(m_{t+1}\right)
\end{aligned}
$$

Then

$$
m_{t+1}=\mathbb{E}_{t}\left[m_{t+1}\right]+\sqrt{\operatorname{var}_{t}\left(m_{t+1}\right)} u_{t+1}=-\bar{r}-e_{r}^{\prime} z_{t}-\frac{1}{2} \operatorname{var}_{t}\left(m_{t+1}\right)+\sqrt{\operatorname{var}_{t}\left(m_{t+1}\right)} u_{t+1} .
$$

Let $P_{t}^{k}$ denote the real price of the risk-free bond with a maturity of $k$ quarters. It satisfies

$$
\begin{aligned}
P_{t}^{1} & =\exp \left(-r_{t}\right)=\exp \left(-\bar{r}-e_{r}^{\prime} z_{t}\right), \\
P_{t}^{k} & =\mathbb{E}_{t}\left[\exp \left(m_{t+1}\right) P_{t+1}^{k-1}\right] .
\end{aligned}
$$

Conjecture $P_{t}^{k}=\exp \left(A_{k}+B_{k}^{\prime} z_{t}\right)$, then

$$
\begin{aligned}
\exp \left(A_{k}+B_{k}^{\prime} z_{t}\right) & =\mathbb{E}_{t}\left[\exp \left(m_{t+1}+A_{k-1}+B_{k-1}^{\prime} z_{t+1}\right)\right] \\
& =\exp \left(-\bar{r}-e_{r}^{\prime} z_{t}+A_{k-1}+B_{k-1}^{\prime} \Psi z_{t}-\frac{1}{2} \operatorname{var}_{t}\left(m_{t+1}\right)+\frac{1}{2}\left(\sqrt{\operatorname{var}_{t}\left(m_{t+1}\right)}+B_{k-1}^{\prime} \Gamma\right)^{2}\right)
\end{aligned}
$$

To obtain a close-form solution, I add a second-order term to the variance of the pricing kernel:

$$
\operatorname{var}_{t}\left(m_{t+1}\right)=2 \bar{v}-2 \gamma e_{x}^{\prime} z_{t}+\frac{1}{2 \bar{v}} \gamma^{2}\left(e_{x}^{\prime} z_{t}\right)^{2}
$$

so that

$$
\sqrt{\operatorname{var}_{t}\left(m_{t+1}\right)}=\sqrt{2 \bar{v}}-\frac{1}{\sqrt{2 \bar{v}}} \gamma e_{x}^{\prime} z_{t}
$$

Then the bond prices have an affine representation:

$$
\begin{aligned}
A_{k} & =A_{k-1}+\frac{1}{2}\left(B_{k-1}^{\prime} \Gamma\right)^{2}+\sqrt{2 \bar{v}} B_{k-1}^{\prime} \Gamma-\bar{r} \\
B_{k}^{\prime} & =B_{k-1}^{\prime} \Psi-\frac{1}{\sqrt{2 \bar{v}}} \gamma B_{k-1}^{\prime} \Gamma e_{x}^{\prime}-e_{r}^{\prime} .
\end{aligned}
$$




\section{Appendix B: Robustness Tests}

\section{B1. Disaggregated by Country}

I disaggregate the single time-series used in Table 1 into a panel of 10 foreign countries. Exchange rates and forward premia are bilateral rates between US and each foreign country. In Table B1, I run the regression in each country's time series. In Table B2, I run a panel regression.

\section{Table B1-Main Regression in Each Country's Time Series.}

\begin{tabular}{rcccccccccc}
\hline \hline country & Australia & Canada & Denmark & Germany & Japan & New Zealand & Norway & Sweden & Switzerland & UK \\
\hline$e$ & 3.69 & 9.13 & 10.12 & 10.38 & 12.98 & -0.69 & 12.92 & 4.39 & 7.54 & 2.01 \\
s.e. & $(2.10)$ & $(1.06)$ & $(1.56)$ & $(1.84)$ & $(4.54)$ & $(2.89)$ & $(2.60)$ & $(2.01)$ & $(1.48)$ & $(1.17)$ \\
R Sq & $55 \%$ & $45 \%$ & $39 \%$ & $39 \%$ & $48 \%$ & $60 \%$ & $38 \%$ & $29 \%$ & $84 \%$ & $26 \%$ \\
\hline$r_{4}$ & 9.01 & 4.69 & 3.74 & 2.65 & 1.05 & 8.96 & 5.15 & 7.59 & 2.81 & 2.25 \\
s.e. & $(2.64)$ & $(1.17)$ & $(1.96)$ & $(1.73)$ & $(3.91)$ & $(1.64)$ & $(2.15)$ & $(1.63)$ & $(1.92)$ & $(1.45)$ \\
R Sq & $22 \%$ & $19 \%$ & $14 \%$ & $15 \%$ & $27 \%$ & $20 \%$ & $14 \%$ & $16 \%$ & $18 \%$ & $9 \%$ \\
\hline$r_{12}$ & 17.15 & 9.81 & 4.46 & 3.49 & 0.11 & 19.46 & 6.71 & 14.43 & 3.67 & 6.99 \\
s.e. & $(5.01)$ & $(2.21)$ & $(4.08)$ & $(3.86)$ & $(7.88)$ & $(5.80)$ & $(5.49)$ & $(4.35)$ & $(4.88)$ & $(2.56)$ \\
R Sq & $35 \%$ & $49 \%$ & $39 \%$ & $37 \%$ & $29 \%$ & $28 \%$ & $48 \%$ & $31 \%$ & $35 \%$ & $24 \%$ \\
\hline \hline
\end{tabular}

Note: Same specification as in Table 1, but only some coefficients are reported. $e$ is the level of dollar index in percentage points; $r_{k}$ is the excess return of the dollar against a basket of foreign currencies in the next $k$ quarters, not annualized and in percentage points. Forward premium and past innovation to Treasury basis are included as controls. Standard errors are HAC-consistent.

Table B2-Panel Regression.

\begin{tabular}{lcccccc}
\hline \hline & \multicolumn{7}{c}{ Dependent variable: } \\
\cline { 2 - 7 } & $e$ & $r_{1}$ & $r_{2}$ & $r_{4}$ & $r_{8}$ & $r_{12}$ \\
& $(1)$ & $(2)$ & $(3)$ & $(4)$ & $(5)$ & $(6)$ \\
\hline US Government Surplus-Debt Ratio (\%) & $5.54^{* * *}$ & 0.90 & $2.02^{*}$ & $4.40^{* *}$ & $8.94^{* *}$ & $13.54^{* *}$ \\
& $(1.03)$ & $(0.64)$ & $(1.19)$ & $(2.19)$ & $(3.92)$ & $(5.65)$ \\
US Treasury Basis (bps) & -0.03 & $-0.04^{* *}$ & $-0.07^{* *}$ & $-0.13^{* *}$ & $-0.21^{* *}$ & -0.22 \\
& $(0.03)$ & $(0.02)$ & $(0.03)$ & $(0.06)$ & $(0.10)$ & $(0.14)$ \\
US Government Debt-GDP Ratio (\%) & $-0.06^{* * *}$ & 0.01 & $0.01^{*}$ & $0.03^{*}$ & $0.05^{* *}$ & $0.07^{* *}$ \\
& $(0.01)$ & $(0.004)$ & $(0.01)$ & $(0.01)$ & $(0.02)$ & $(0.03)$ \\
Forward Premium (\%) & $2.64^{* *}$ & 0.18 & -0.14 & -1.02 & -1.63 & -0.96 \\
& $(1.17)$ & $(0.88)$ & $(1.62)$ & $(2.49)$ & $(3.91)$ & $(4.96)$ \\
\hline Observations & 1,298 & 1,298 & 1,298 & 1,298 & 1,298 & 1,298 \\
$\mathrm{R}^{2}$ & 0.28 & 0.06 & 0.07 & 0.09 & 0.09 & 0.09 \\
$\mathrm{R}^{2}$ without Surplus-Debt Ratio & 0.23 & 0.05 & 0.06 & 0.06 & 0.06 & 0.05 \\
\hline \hline
\end{tabular}

Note: I report the results of the panel regressions with country-level fixed effects. Data are quarterly and start from 1988. Errors are clustered by time, and the standard errors are calculated using Arellano (1987) which corrects for heteroskedasticity and autocorrelation. ${ }^{*} \mathrm{p}<0.1 ;{ }^{* *} \mathrm{p}<0.05 ;{ }^{* * *} \mathrm{p}<0.01$. 


\section{B2. Explaining the Exchange Rate Movement}

In Table B3, I repeat the main specification but use the nominal exchange rate movement instead of the currency excess return as the dependent variable.

\section{Table B3-What Explains The Dollar's Value and Future Exchange Rate} MOVEMENT.

\begin{tabular}{|c|c|c|c|c|c|c|}
\hline & \multicolumn{6}{|c|}{ Dependent variable: } \\
\hline & $e$ & $d q_{1}$ & $d q_{2}$ & $d q_{4}$ & $d q_{8}$ & $d q_{12}$ \\
\hline & $(1)$ & $(2)$ & $(3)$ & $(4)$ & $(5)$ & $(6)$ \\
\hline US Government Surplus-Debt Ratio (\%) & $\begin{array}{l}9.66^{* * *} \\
(1.92)\end{array}$ & $\begin{array}{c}1.31 \\
(0.88)\end{array}$ & $\begin{array}{l}2.57^{* * *} \\
(0.86)\end{array}$ & $\begin{array}{l}5.40^{* * *} \\
(0.88)\end{array}$ & $\begin{array}{l}7.59^{* * *} \\
(2.05)\end{array}$ & $\begin{array}{l}7.26^{* *} \\
(3.65)\end{array}$ \\
\hline US Treasury Basis (bps) & $\begin{array}{c}-0.05 \\
(0.06)\end{array}$ & $\begin{array}{c}-0.04^{* *} \\
(0.02)\end{array}$ & $\begin{array}{r}-0.04^{*} \\
(0.02)\end{array}$ & $\begin{array}{c}-0.04 \\
(0.04)\end{array}$ & $\begin{array}{c}0.003 \\
(0.05)\end{array}$ & $\begin{array}{c}0.02 \\
(0.04)\end{array}$ \\
\hline US Government Debt-GDP Ratio (\%) & $\begin{array}{c}-0.06^{* * *} \\
(0.02)\end{array}$ & $\begin{array}{c}0.01^{*} \\
(0.005)\end{array}$ & $\begin{array}{c}0.01 \\
(0.01)\end{array}$ & $\begin{array}{c}0.03^{* *} \\
(0.01)\end{array}$ & $\begin{array}{l}0.07^{* * *} \\
(0.02)\end{array}$ & $\begin{array}{l}0.12^{* * *} \\
(0.03)\end{array}$ \\
\hline Forward Premium (\%) & $\begin{array}{r}-6.25^{*} \\
(3.35) \\
\end{array}$ & $\begin{array}{c}-1.61 \\
(1.32) \\
\end{array}$ & $\begin{array}{c}-2.30 \\
(1.68) \\
\end{array}$ & $\begin{array}{c}-4.10 \\
(3.16) \\
\end{array}$ & $\begin{array}{c}-2.55 \\
(5.39) \\
\end{array}$ & $\begin{array}{c}0.34 \\
(6.65) \\
\end{array}$ \\
\hline Observations & 118 & 118 & 118 & 116 & 112 & 108 \\
\hline $\mathrm{R}^{2}$ & 0.51 & 0.10 & 0.09 & 0.16 & 0.24 & 0.37 \\
\hline
\end{tabular}

Note: Dependent variables: $e$ is the level of dollar index in percentage points; $d q_{k}$ is the nominal exchange rate movement of the dollar against a basket of foreign currencies in the next $k$ quarters, not annualized and in percentage points. Explanatory variables: forward premium and past innovation to Treasury basis are included as controls. The constant is not reported. Standard errors are HAC-consistent. ${ }^{*} \mathrm{p}<0.1 ;{ }^{* *} \mathrm{p}<0.05$; ${ }^{* * *} \mathrm{p}<0.01$. 


\section{B3. Alternative Weights and Adjustments}

In Table B4, I repeat the main specification using trade-weighted exchange rates and currency returns. The weights are total trade weights provided in Foreign Exchange Rates - H.10 by the Federal Reserve Board. The weights are updated on an annual basis. In each year, I use the trade weighted based on the trade data in the previous year.

\section{Table B4-What Explains Dollar's Value and Future Return, Trade- Weighted Time Series.}

\begin{tabular}{|c|c|c|c|c|c|c|}
\hline & \multicolumn{6}{|c|}{ Dependent variable: } \\
\hline & $e$ & $r_{1}$ & $r_{2}$ & $r_{4}$ & $r_{8}$ & $r_{12}$ \\
\hline & $(1)$ & $(2)$ & $(3)$ & $(4)$ & $(5)$ & $(6)$ \\
\hline US Government Surplus-Debt Ratio (\%) & $\begin{array}{l}7.34^{* * *} \\
(1.33)\end{array}$ & $\begin{array}{c}0.61 \\
(0.49)\end{array}$ & $\begin{array}{l}1.37^{* *} \\
(0.68)\end{array}$ & $\begin{array}{l}3.01^{* * *} \\
(0.75)\end{array}$ & $\begin{array}{l}5.33^{* * *} \\
(1.27)\end{array}$ & $\begin{array}{c}5.72^{* *} \\
(2.42)\end{array}$ \\
\hline US Treasury Basis (bps) & $\begin{array}{c}-0.04 \\
(0.04)\end{array}$ & $\begin{array}{c}-0.03^{*} \\
(0.01)\end{array}$ & $\begin{array}{c}-0.02 \\
(0.02)\end{array}$ & $\begin{array}{c}-0.01 \\
(0.03)\end{array}$ & $\begin{array}{c}0.03 \\
(0.03)\end{array}$ & $\begin{array}{c}0.04 \\
(0.03)\end{array}$ \\
\hline US Government Debt-GDP Ratio (\%) & $\begin{array}{c}-0.03 \\
(0.02)\end{array}$ & $\begin{array}{c}0.01 \\
(0.003)\end{array}$ & $\begin{array}{c}0.01^{*} \\
(0.01)\end{array}$ & $\begin{array}{l}0.03^{* * *} \\
(0.01)\end{array}$ & $\begin{array}{l}0.07^{* * *} \\
(0.01)\end{array}$ & $\begin{array}{l}0.11^{* * *} \\
(0.01)\end{array}$ \\
\hline Forward Premium (\%) & $\begin{array}{c}-11.35^{* * *} \\
(3.42) \\
\end{array}$ & $\begin{array}{c}0.99 \\
(0.83) \\
\end{array}$ & $\begin{array}{c}2.69^{* *} \\
(1.26) \\
\end{array}$ & $\begin{array}{c}5.79^{* *} \\
(2.59) \\
\end{array}$ & $\begin{array}{l}11.08^{* *} \\
(4.76)\end{array}$ & $\begin{array}{l}14.03^{* * *} \\
(5.31) \\
\end{array}$ \\
\hline Observations & 118 & 118 & 118 & 116 & 112 & 108 \\
\hline $\mathrm{R}^{2}$ & 0.51 & 0.10 & 0.14 & 0.31 & 0.48 & 0.56 \\
\hline
\end{tabular}

Note: Dependent variables: $e$ is the level of dollar index in percentage points; $r_{k}$ is the excess return of the dollar against a basket of foreign currencies in the next $k$ quarters, not annualized and in percentage points. Explanatory variables: forward premium and past innovation to Treasury basis are included as controls. The constant is not reported. Standard errors are HAC-consistent. ${ }^{*} \mathrm{p}<0.1 ;{ }^{* *} \mathrm{p}<0.05 ;{ }^{* * *} \mathrm{p}<0.01$. 
In Table B5, I run the univariate regression of currency value and future returns on the surplus-to-debt ratio, and report the point estimates after the Stambaugh (1999) adjustment.

\section{Table B5-What Explains Dollar's Value and Future Return, Stambaugh (1999) Adjustment.}

\begin{tabular}{lllllll}
\hline \hline & \multicolumn{7}{c}{ Dependent variable: } \\
\cline { 2 - 8 } & $e$ & $r_{1}$ & $r_{2}$ & $r_{4}$ & $r_{8}$ & $r_{12}$ \\
& $(1)$ & $(2)$ & $(3)$ & $(4)$ & $(5)$ & $(6)$ \\
\hline US Government Surplus-Debt Ratio $(\%)$ & $9.70^{* * *}$ & $1.13^{*}$ & $2.20^{* * *}$ & $4.27^{* * *}$ & $5.30^{* *}$ & 3.02 \\
Before Adjustment & $9.25^{* * *}$ & $1.31^{* *}$ & $2.47^{* * *}$ & $4.66^{* * *}$ & $6.33^{* * *}$ & 4.44 \\
& $(1.68)$ & $(0.58)$ & $(0.78)$ & $(1.11)$ & $(2.20)$ & $(3.39)$ \\
\hline Observations & 118 & 118 & 118 & 116 & 112 & 108 \\
$\mathrm{R}^{2}$ & 0.28 & 0.05 & 0.07 & 0.13 & 0.11 & 0.04 \\
\hline \hline
\end{tabular}

Note: Dependent variables: $e$ is the level of dollar index in percentage points; $r_{k}$ is the excess return of the dollar against a basket of foreign currencies in the next $k$ quarters, not annualized and in percentage points. Standard errors are HAC-consistent. ${ }^{*} \mathrm{p}<0.1 ;{ }^{* *} \mathrm{p}<0.05 ;{ }^{* * *} \mathrm{p}<0.01$.

In Table 1 in the main text, I report the standard Newey-West standard errors. In Table B6, I report the standard errors that use a truncation parameter of $1.3 T^{1 / 2}$ to capture the long-run covariance (Lazarus et al. (2018)).

Table B6-What Explains Dollar's Value and Future Return, Lazarus et al. (2018) STANDARD ERrors.

\begin{tabular}{lcccccc}
\hline \hline & \multicolumn{7}{c}{ Dependent variable: } \\
\cline { 2 - 7 } & $e$ & $r_{1}$ & $r_{2}$ & $r_{4}$ & $r_{8}$ & $r_{12}$ \\
& $(1)$ & $(2)$ & $(3)$ & $(4)$ & $(5)$ & $(6)$ \\
\hline US Government Surplus-Debt Ratio (\%) & $9.66^{* * *}$ & $1.31^{* * *}$ & $2.58^{* * *}$ & $5.43^{* * *}$ & $7.64^{* * *}$ & 7.21 \\
& $(1.93)$ & $(0.28)$ & $(0.38)$ & $(0.70)$ & $(2.65)$ & $(4.75)$ \\
US Treasury Basis (bps) & -0.05 & $-0.04^{* * *}$ & $-0.04^{* *}$ & -0.03 & 0.01 & $0.05^{*}$ \\
& $(0.06)$ & $(0.01)$ & $(0.02)$ & $(0.04)$ & $(0.05)$ & $(0.03)$ \\
US Government Debt-GDP Ratio (\%) & $-0.06^{*}$ & $0.01^{* *}$ & $0.01^{* *}$ & $0.03^{* *}$ & $0.08^{* * *}$ & $0.13^{* * *}$ \\
& $(0.03)$ & $(0.003)$ & $(0.01)$ & $(0.01)$ & $(0.02)$ & $(0.02)$ \\
Forward Premium (\%) & $-6.25^{*}$ & -0.61 & -0.35 & -0.46 & 3.61 & 7.86 \\
& $(3.24)$ & $(0.73)$ & $(1.59)$ & $(3.30)$ & $(5.70)$ & $(6.85)$ \\
\hline Observations & 118 & 118 & 118 & 116 & 112 & 108 \\
$\mathrm{R}^{2}$ & 0.51 & 0.11 & 0.12 & 0.21 & 0.32 & 0.43 \\
\hline \hline
\end{tabular}

Note: Dependent variables: $e$ is the level of dollar index in percentage points; $r_{k}$ is the excess return of the dollar against a basket of foreign currencies in the next $k$ quarters, not annualized and in percentage points. Standard errors are HAC-consistent with a truncation parameter of $1.3 T^{1 / 2}{ }^{*} \mathrm{p}<0.1 ;{ }^{* *} \mathrm{p}<0.05 ;{ }^{* * *} \mathrm{p}<0.01$. 


\section{B4. Alternative Data Source}

In Table B7, I use an alternative dataset of quarterly US government surpluses from Thomson Reuters International Comparable Economics (TRICE). This database contains each country's government surplus in the unit of US dollar.

Table B7-Alternative Database, TRICE Data.

\begin{tabular}{lcccccc}
\hline \hline & \multicolumn{7}{c}{ Dependent variable: } & & \\
\cline { 2 - 7 } & $e$ & $r_{1}$ & $r_{2}$ & $r_{4}$ & $r_{8}$ & $r_{12}$ \\
& $(1)$ & $(2)$ & $(3)$ & $(4)$ & $(5)$ & $(6)$ \\
\hline US Treasury Basis (bps) & $-0.25^{* *}$ & -0.02 & -0.02 & -0.01 & 0.09 & $0.18^{* * *}$ \\
& $(0.10)$ & $(0.03)$ & $(0.07)$ & $(0.08)$ & $(0.08)$ & $(0.05)$ \\
US Government Debt-GDP Ratio (\%) & $-0.07^{* *}$ & 0.01 & 0.01 & 0.03 & $0.06^{* *}$ & $0.11^{* * *}$ \\
& $(0.03)$ & $(0.004)$ & $(0.01)$ & $(0.02)$ & $(0.03)$ & $(0.03)$ \\
US Government Surplus-Debt Ratio (\%) & $2.95^{* * *}$ & 0.24 & 0.57 & $2.02^{* * *}$ & $2.73^{* *}$ & 2.26 \\
& $(0.42)$ & $(0.29)$ & $(0.42)$ & $(0.60)$ & $(1.14)$ & $(1.74)$ \\
Forward Premium (\%) & -2.14 & 0.70 & 1.83 & 3.11 & 9.00 & $13.74^{*}$ \\
& $(2.53)$ & $(1.02)$ & $(1.83)$ & $(3.46)$ & $(6.20)$ & $(7.40)$ \\
Past Innovation to Treasury Basis (bps) & $0.21^{* * *}$ & -0.04 & -0.02 & -0.05 & $-0.12^{* *}$ & $-0.17^{* * *}$ \\
& $(0.07)$ & $(0.04)$ & $(0.07)$ & $(0.05)$ & $(0.06)$ & $(0.05)$ \\
\hline Observations & 117 & 117 & 117 & 115 & 111 & 107 \\
$\mathrm{R}^{2}$ & 0.46 & 0.09 & 0.08 & 0.16 & 0.27 & 0.39 \\
$\mathrm{R}^{2}$ without Surplus-Debt Ratio & 0.41 & 0.09 & 0.07 & 0.11 & 0.23 & 0.37 \\
\hline \hline
\end{tabular}

Note: Government surpluses are from Thomson Reuters International Comparable Economics (TRICE). Data are quarterly and start from 1988. The constant is not reported. Standard errors are HAC-consistent. ${ }^{*} \mathrm{p}<0.1 ;{ }^{* *} \mathrm{p}<0.05 ;{ }^{* * *} \mathrm{p}<0.01$. 
I use an alternative dataset of quarterly US government surpluses, government debt, GDP, and trade-weighted real dollar index from Federal Reserve Economic Data (FRED). The data start at 1973. In this dataset, US government surpluses have strong seasonal effects and the dollar index has a strong trend. I do not find significant results using the raw data.

In Table B8, I use the five-year changes in US government surplus-to-debt ratio, in US government debt-toGDP ratio, and in the dollar index. The US government surplus-to-debt ratio predicts future dollar exchange rate movement, but does not explain dollar exchange rate movement in the earlier part of the sample.

In Table B9, I repeat the regression using the subsample starting from 1988. In this subsample, the US government surplus-to-debt ratio also explains the dollar exchange rate movement.

Table B8-Alternative Database, FRED Data.

\begin{tabular}{lccccccc}
\hline \hline & \multicolumn{7}{c}{ Dependent variable: } \\
\cline { 2 - 8 } & $q$ & $d q_{1}$ & $d q_{2}$ & $d q_{4}$ & $d q_{8}$ & $d q_{12}$ \\
& $(1)$ & $(2)$ & $(3)$ & $(4)$ & $(5)$ & $(6)$ \\
\hline US Government Surplus-Debt Ratio (\%) & 1.08 & 0.15 & $0.40^{*}$ & $1.01^{* *}$ & $2.03^{* * *}$ & $2.79^{* * *}$ \\
& $(2.60)$ & $(0.11)$ & $(0.24)$ & $(0.43)$ & $(0.69)$ & $(0.70)$ \\
US Government Debt-GDP Ratio (\%) & $-0.33^{*}$ & -0.002 & -0.003 & 0.02 & 0.12 & 0.30 \\
& $(0.19)$ & $(0.01)$ & $(0.03)$ & $(0.07)$ & $(0.14)$ & $(0.23)$ \\
\hline Observations & 156 & 175 & 174 & 172 & 168 & 164 \\
$\mathrm{R}^{2}$ & 0.06 & 0.01 & 0.04 & 0.10 & 0.16 & 0.20 \\
\hline \hline
\end{tabular}

Note: The dependent variable $d q_{k}$ is the movement of the US dollar index in the next $k$ quarters. Data are quarterly and start from 1973. US government surplus-to-debt ratio, US government debt-to-GDP ratio, and the dollar index $e$ are the changes relative to their value five years ago. The constant is not reported. Standard errors are HAC-consistent. ${ }^{*} \mathrm{p}<0.1 ;{ }^{* *} \mathrm{p}<0.05 ;{ }^{* * *} \mathrm{p}<0.01$.

Table B9-Alternative Database, FRed Data, Starting from 1988.

\begin{tabular}{lcccccc}
\hline \hline & \multicolumn{7}{c}{ Dependent variable: } \\
\cline { 2 - 8 } & $q$ & $d q_{1}$ & $d q_{2}$ & $d q_{4}$ & $d q_{8}$ & $d q_{12}$ \\
& $(1)$ & $(2)$ & $(3)$ & $(4)$ & $(5)$ & $(6)$ \\
\hline US Government Surplus-Debt Ratio (\%) & $3.66^{* * *}$ & $0.43^{* * *}$ & $0.84^{* * *}$ & $1.67^{* * *}$ & $2.95^{* * *}$ & $3.58^{* * *}$ \\
& $(0.94)$ & $(0.11)$ & $(0.16)$ & $(0.21)$ & $(0.40)$ & $(0.49)$ \\
US Government Debt-GDP Ratio (\%) & $-0.43^{* * *}$ & 0.01 & 0.03 & $0.09^{* *}$ & $0.27^{* * *}$ & $0.51^{* * *}$ \\
& $(0.11)$ & $(0.01)$ & $(0.02)$ & $(0.04)$ & $(0.07)$ & $(0.12)$ \\
\hline Observations & 117 & 116 & 115 & 113 & 109 & 105 \\
$\mathrm{R}^{2}$ & 0.33 & 0.12 & 0.19 & 0.37 & 0.56 & 0.60 \\
\hline \hline
\end{tabular}


Figure B1 reports the five-year change in US government surplus-to-debt ratio and the future movement in the dollar index in the next four quarters.

\section{Figure B1. US Government Surplus-to-Debt Ratio, FRed Data.}
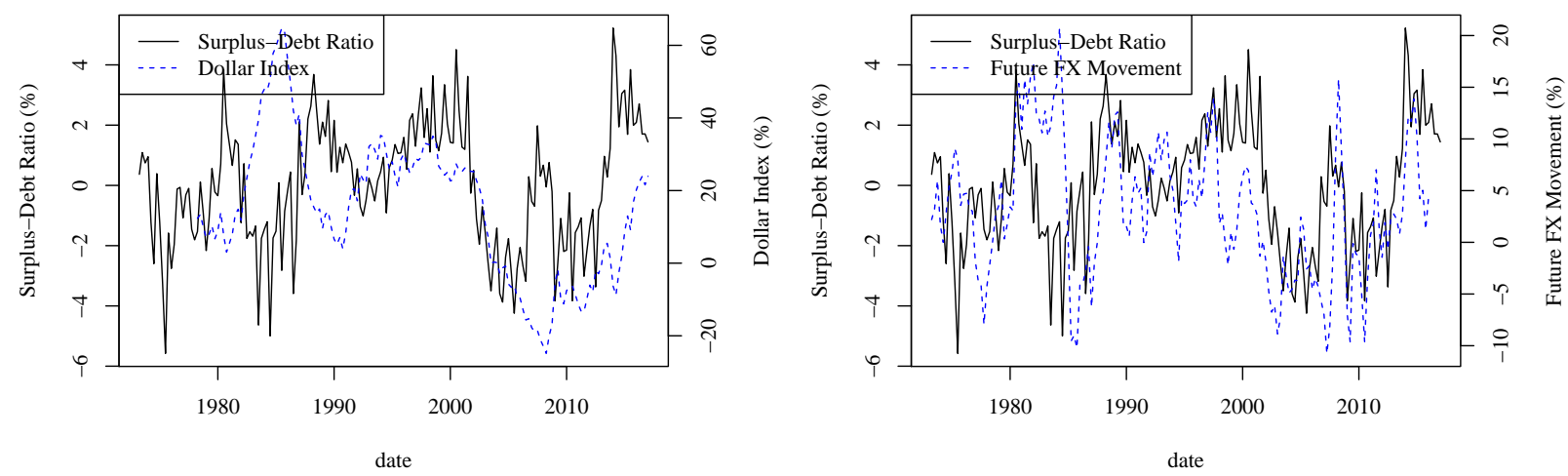

Note: Left figure: US government surplus-to-debt ratio and the dollar index $q$. Right figure: US government surplus-to-debt ratio and the movement of the dollar index in the next four quarters $d q_{4}$. US government surplus-to-debt ratio and the dollar index $e$ are the changes relative to their value five years ago. 


\section{B5. Horse Races}

In Table B10, I run a horse race between the US government surplus-to-debt ratio, the US government debt-to-GDP ratio and the US current account-to-GDP ratio.

\section{Table B10-Horse Race with US Current Account-GDP Ratio.}

\begin{tabular}{lccccccc}
\hline \hline & \multicolumn{7}{c}{ Dependent variable: } \\
\cline { 2 - 8 } & $e$ & $r_{1}$ & $r_{2}$ & $r_{4}$ & $r_{8}$ & $r_{12}$ \\
& $(1)$ & $(2)$ & $(3)$ & $(4)$ & $(5)$ & $(6)$ \\
\hline US Government Surplus-Debt Ratio (\%) & $7.51^{* * *}$ & $1.44^{* *}$ & $2.78^{* * *}$ & $5.54^{* * *}$ & $8.97^{* * *}$ & $10.06^{* * *}$ \\
& $(1.39)$ & $(0.64)$ & $(0.89)$ & $(1.24)$ & $(2.20)$ & $(3.75)$ \\
US Current Account-GDP Ratio (\%) & 1.14 & 0.07 & 0.12 & 0.57 & 1.29 & 1.89 & $(1.69)$ \\
& $(1.20)$ & $(0.28)$ & $(0.49)$ & $(0.51)$ & $(0.94)$ & $0.13^{* * *}$ \\
US Government Debt-GDP Ratio (\%) & $-0.07^{* * *}$ & 0.005 & 0.01 & $0.03^{* *}$ & $0.07^{* * *}$ & $(0.02)$ \\
\hline Observations & $(0.02)$ & $(0.005)$ & $(0.01)$ & $(0.01)$ & $(0.02)$ & 112 & 108 \\
$\mathrm{R}^{2}$ & 118 & 118 & 118 & 116 & 112 & 0.43 \\
\hline \hline
\end{tabular}

Note: I repeat the time-series regression in Table 1 with additional explanatory variables. Standard errors are HAC-consistent. ${ }^{*} \mathrm{p}<0.1 ;{ }^{* *} \mathrm{p}<0.05 ;{ }^{* * *} \mathrm{p}<0.01$.

In Table B11, I run a horse race between the US government surplus-to-debt ratio, the US government debt-toGDP ratio and the cyclically-adjusted measure of imbalance NXA in Gourinchas and Rey (2007, 2014); Gourinchas, Rey and Sauzet (2018).

\section{Table B11-Horse Race with the Cyclically-Adjusted Measure of Imbal- ANCE NXA.}

\begin{tabular}{lccccccc}
\hline \hline & \multicolumn{7}{c}{ Dependent variable: } \\
\cline { 2 - 8 } & $e$ & $r_{1}$ & $r_{2}$ & $r_{4}$ & $r_{8}$ & $r_{12}$ \\
& $(1)$ & $(2)$ & $(3)$ & $(4)$ & $(5)$ & $(6)$ \\
\hline US Government Surplus-Debt Ratio (\%) & $7.52^{* * *}$ & $1.41^{* *}$ & $2.66^{* * *}$ & $5.13^{* * *}$ & $7.12^{* * *}$ & $7.65^{*}$ \\
& $(1.67)$ & $(0.70)$ & $(0.89)$ & $(1.01)$ & $(2.21)$ & $(4.33)$ \\
NXA (\%) & $-0.33^{* * *}$ & 0.04 & 0.11 & $0.23^{*}$ & $0.51^{* * *}$ & $0.53^{*}$ \\
& $(0.09)$ & $(0.04)$ & $(0.07)$ & $(0.13)$ & $(0.14)$ & $(0.28)$ & $0.07^{* *}$ \\
US Government Debt-GDP Ratio (\%) & $-0.05^{* * *}$ & 0.002 & 0.004 & 0.01 & 0.02 & $(0.03)$ \\
\hline Observations & $(0.02)$ & $(0.01)$ & $(0.01)$ & $(0.01)$ & $(0.02)$ & 112 & 108 \\
$\mathrm{R}^{2}$ & 112 & 112 & 112 & 112 & 12 & 0.50 \\
\hline \hline
\end{tabular}

Note: I repeat the time-series regression in Table 1 with additional explanatory variables. Standard errors are HAC-consistent. ${ }^{*} \mathrm{p}<0.1 ;{ }^{* *} \mathrm{p}<0.05 ;{ }^{* * *} \mathrm{p}<0.01$. 


\section{B6. Impulse Response Functions with Alternative Orderings}

Figure B2. Impulse Responses, Alternative Ordering.
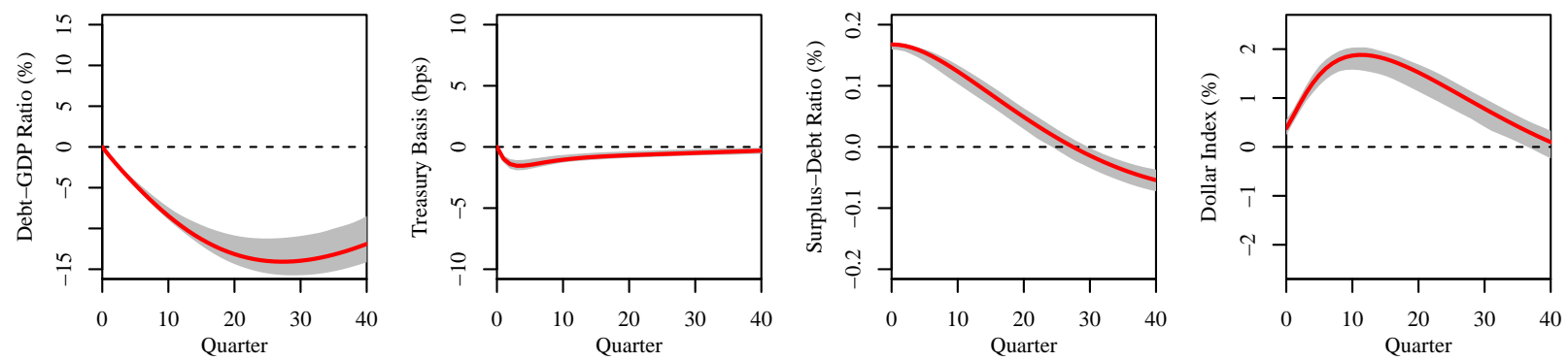

(a) Impulse Responses to a Government Surplus-to-Debt Shock.
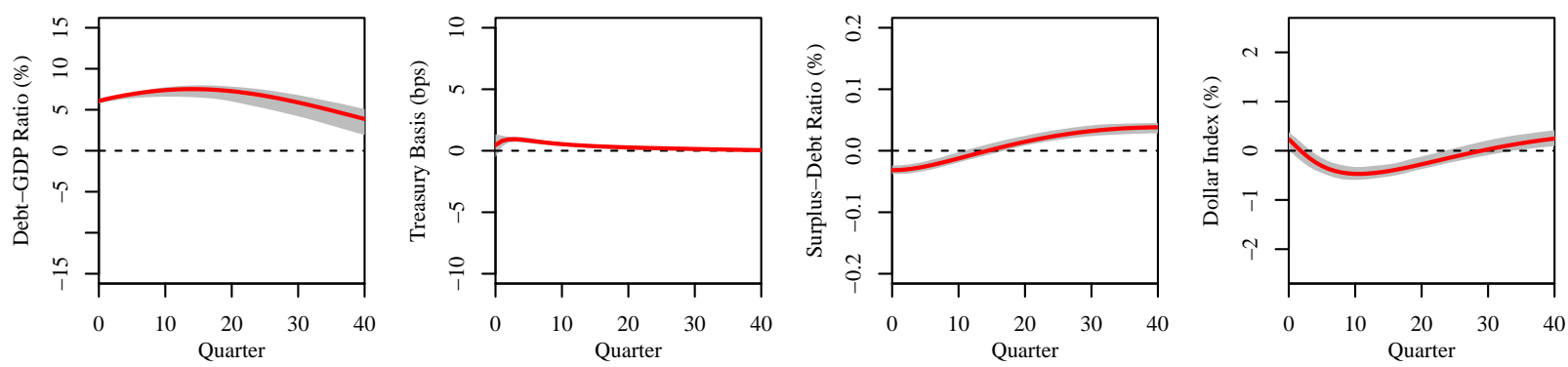

(b) Impulse Responses to a Government Debt-to-GDP Shock.
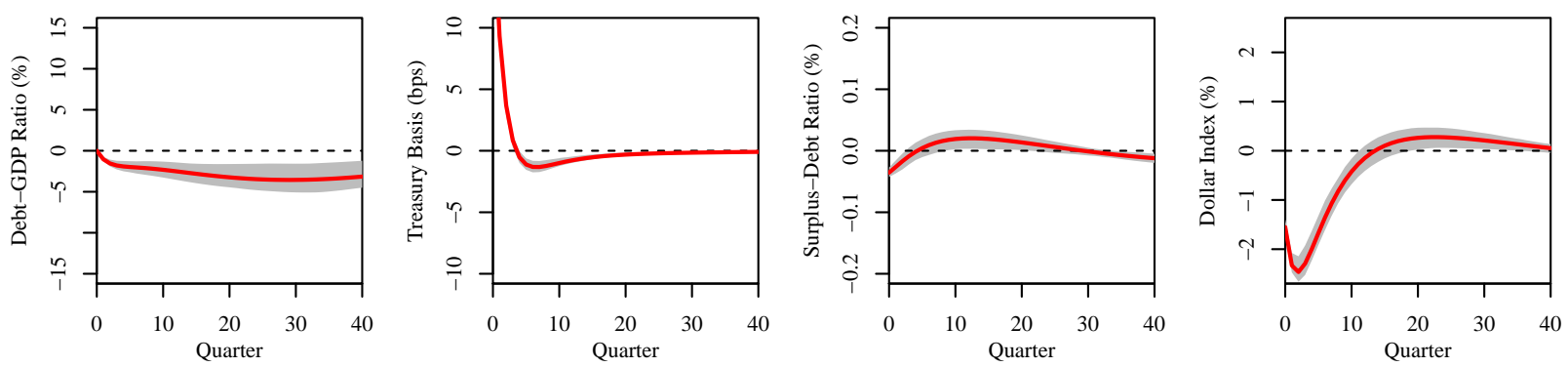

(c) Impulse Responses to a Treasury Basis Shock.
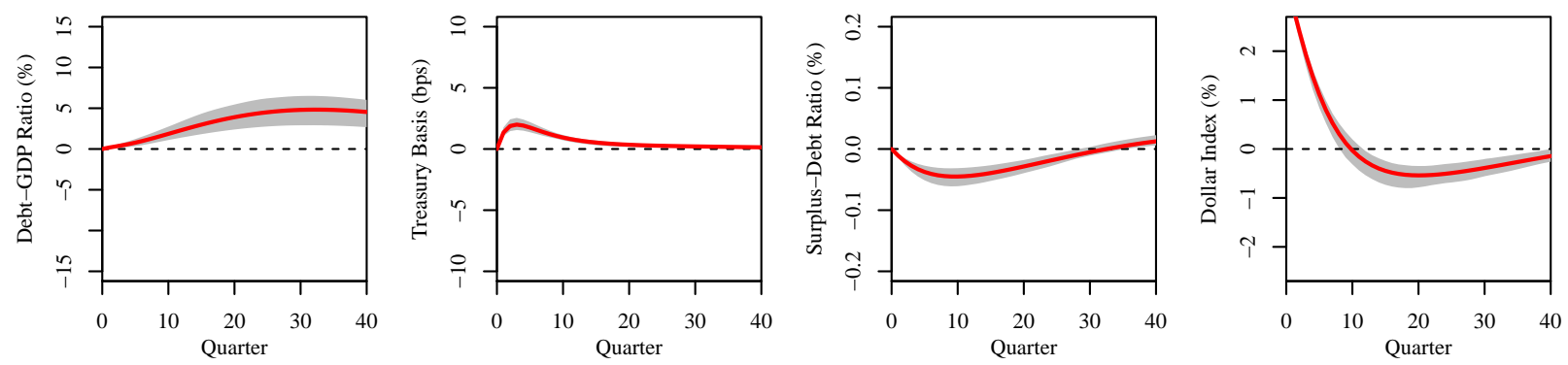

(d) Impulse Responses to a Cumulative Dollar Return Shock.

Note: The order of the VAR variables is US governmegrt debt-to-GDP ratio, US Treasury basis, US government surplus-to-debt ratio, and the dollar index. 
Figure B3. Variance Decomposition, Alternative Ordering.

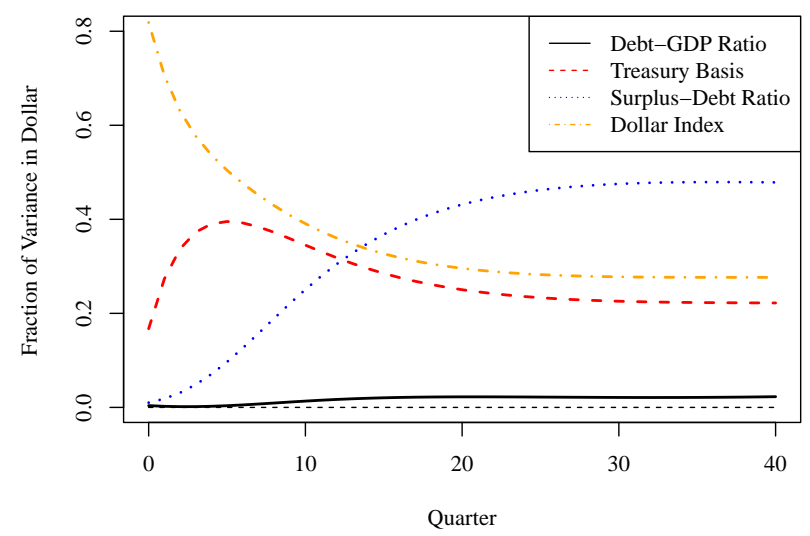

Note: This panel plots the variance of forecast error due to each orthogonalized shock, as implied from the VAR system. The order of the VAR variables is US government debt-to-GDP ratio, US Treasury basis, US government surplus-to-debt ratio, and the dollar index. 
Figure B4. Impulse Responses, Alternative Ordering.
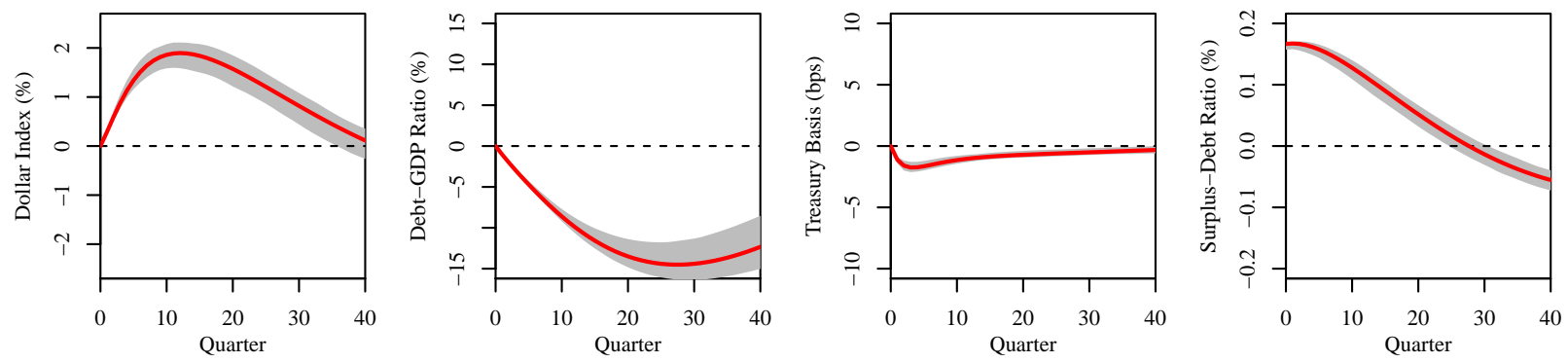

(a) Impulse Responses to a Government Surplus-to-Debt Shock.
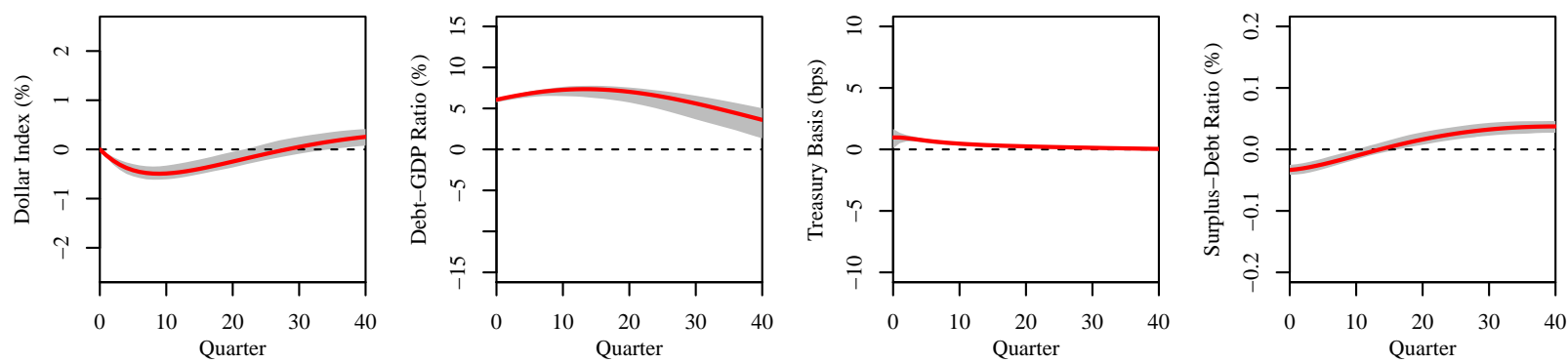

(b) Impulse Responses to a Government Debt-to-GDP Shock.
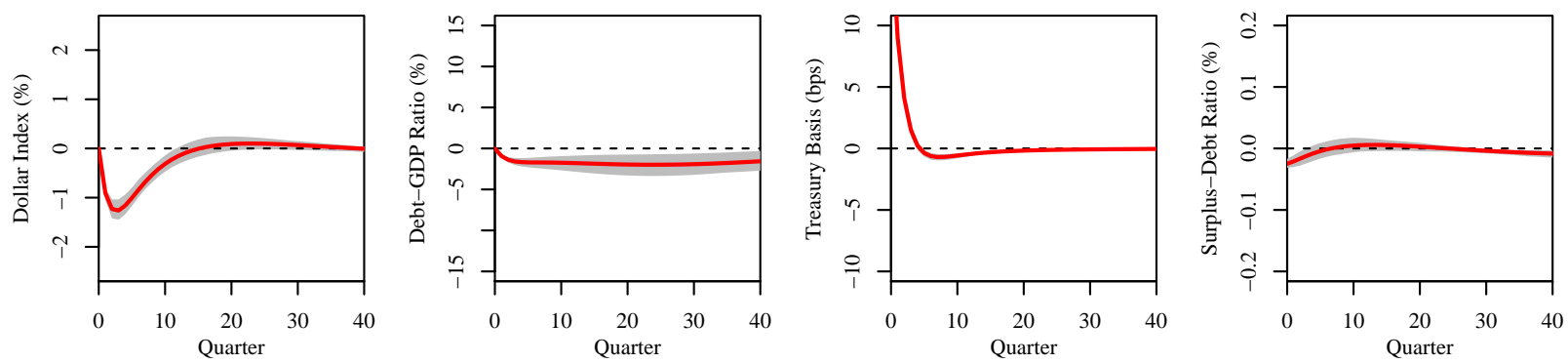

(c) Impulse Responses to a Treasury Basis Shock.
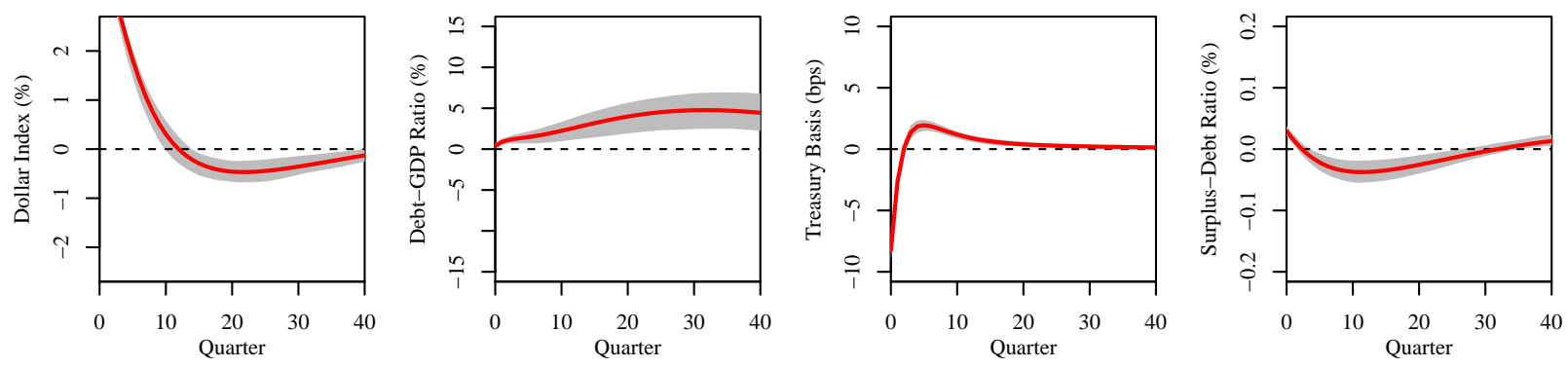

(d) Impulse Responses to a Cumulative Dollar Return Shock.

Note: The order of the VAR variables is the dollar index, US government debt-to-GDP ratio, US Treasury basis, and US government surplus-to-debt ratio. 
Figure B5. Variance Decomposition, Alternative Ordering.

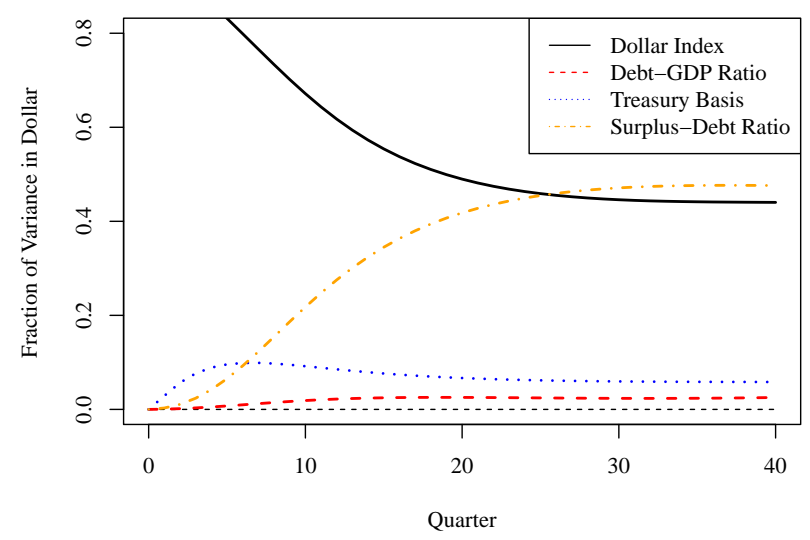

Note: This panel plots the variance of forecast error due to each orthogonalized shock, as implied from the VAR system. The order of the VAR variables is the dollar index, US government debt-to-GDP ratio, US Treasury basis, and US government surplus-to-debt ratio. 


\section{Appendix C: Additional Empirical Results on Asset Pricing Patterns}

\section{C1. Forward Premium Puzzle}

Table C1 shows that both the dollar's forward premium and the dollar's excess return are driven by the US government surplus-to-debt ratio-The US government surplus-to-debt ratio explains $43 \%$ of the variation in the dollar's forward premium against the basket of foreign currencies, and $18 \%$ in the dollar's excess return in the next 4 quarters. Once I control for the US government surplus-to-debt ratio, the dollar's forward premium no longer predicts the dollar's excess return in the next 4 quarters.

Moreover, Engel (2016) shows that not only does a higher forward premium predict a higher excess return on the dollar in the short run, but it also predicts a lower excess return on the dollar in the long run. In the single time series of the dollar against the basket of 10 foreign currencies, I regress the dollar's cumulative excess return in the next $h$ quarters on the dollar's current forward premium:

$$
r_{t, h}=\alpha_{h}+\beta_{h} f p_{t}+\varepsilon_{t+h}^{h}
$$

The left panel of Figure C1 reports the coefficient $\beta_{h}$ as a function of the forecast horizon $h$. This coefficient is positive in the short run and negative in the long run, confirming the finding in Engel (2016).

Then, I regress the dollar's cumulative excess return in the next $h$ quarters on the dollar's forward premium and

Table C1-US Fiscal Cycle Explains Forward Premia.

\begin{tabular}{|c|c|c|c|c|c|c|c|c|}
\hline & \multicolumn{8}{|c|}{ Dependent variable: } \\
\hline & \multicolumn{3}{|c|}{ (1)-(3): Forward Premium } & \multicolumn{5}{|c|}{ (4)-(8): Future Dollar Excess Return } \\
\hline & $(1)$ & $(2)$ & $(3)$ & $(4)$ & $(5)$ & $(6)$ & (7) & $(8)$ \\
\hline US Government Surplus-Debt Ratio (\%) & $\begin{array}{l}0.43^{* * *} \\
(0.14)\end{array}$ & & $\begin{array}{l}0.44^{* * *} \\
(0.14)\end{array}$ & & $\begin{array}{l}6.01^{* * *} \\
(1.77)\end{array}$ & $\begin{array}{l}4.45^{* * *} \\
(1.65)\end{array}$ & & $\begin{array}{l}5.95^{* * *} \\
(1.28)\end{array}$ \\
\hline US Government Debt-GDP Ratio (\%) & & $\begin{array}{c}0.001 \\
(0.001)\end{array}$ & $\begin{array}{c}0.001^{*} \\
(0.001)\end{array}$ & & & & $\begin{array}{c}0.03^{*} \\
(0.01)\end{array}$ & $\begin{array}{l}0.04^{* * *} \\
(0.01)\end{array}$ \\
\hline Forward Premium (\%) & & & & $\begin{array}{r}8.04^{*} \\
(4.54) \\
\end{array}$ & & $\begin{array}{c}3.67 \\
(4.64)\end{array}$ & $\begin{array}{c}7.54 \\
(4.82) \\
\end{array}$ & $\begin{array}{c}1.50 \\
(4.09)\end{array}$ \\
\hline Observations & 133 & 133 & 133 & 130 & 130 & 130 & 130 & 130 \\
\hline $\mathrm{R}^{2}$ & 0.43 & 0.02 & 0.47 & 0.14 & 0.18 & 0.20 & 0.19 & 0.29 \\
\hline
\end{tabular}

Note: Dependent variables are the forward premium of the dollar against the basket of foreign currencies $(f p)$, and the dollar excess return in the next 4 quarters $\left(r_{4}\right)$. A higher forward premium means a higher US nominal interest rate relative to foreign nominal interest rates. Standard errors are HAC-consistent. ${ }^{*} \mathrm{p}<0.1$; ${ }^{* *} \mathrm{p}<0.05 ;{ }^{* * *} \mathrm{p}<0.01$. 
the US government's surplus-to-debt ratio:

$$
r_{t, h}=\alpha_{h}+\beta_{h} f p_{t}+\gamma_{h} \frac{\text { surplus }_{t}}{\text { debt }_{t-1}}+\varepsilon_{t+h}^{h}
$$

The right panel of Figure C1 reports the coefficients $\beta_{h}$ and $\gamma_{h}$ in this bivariate regression. A higher US forward premium predicts a higher excess return on the dollar regardless of the forecast horizon $h$, whereas a higher US government surplus-to-debt ratio predicts a higher excess return on the dollar in the short run and a lower excess return in the long run.

\section{Figure C1. Expected Cumulative Excess Returns of the Dollar.}
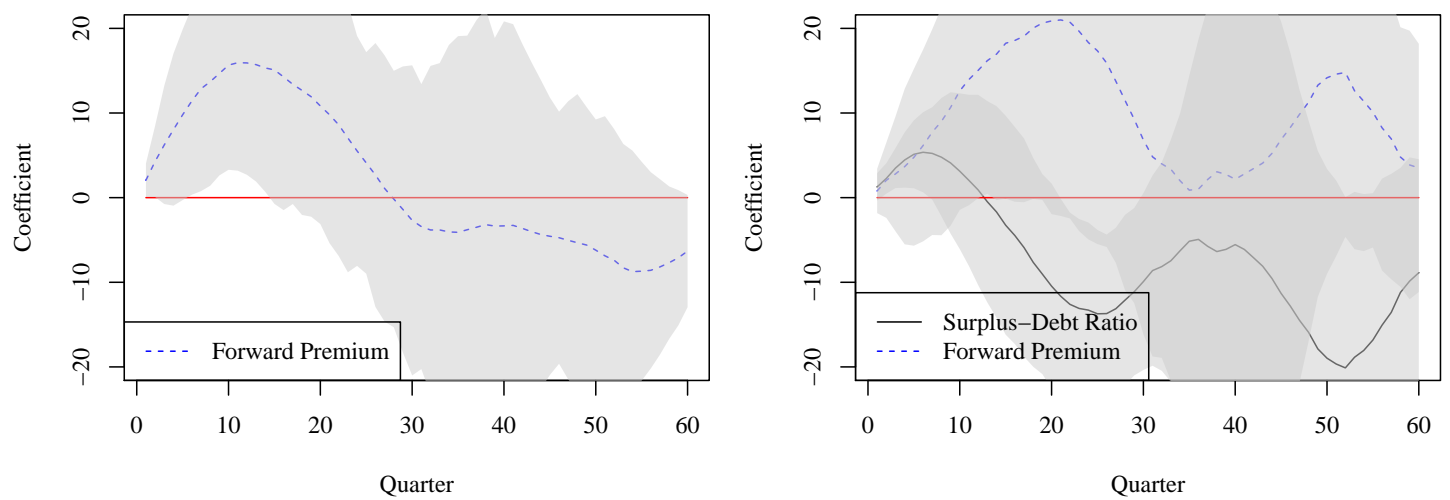

Note: I report the point estimates and the $95 \%$ confidence intervals of the regressions coefficients $\beta_{h}$ and $\gamma_{h}$ as functions of the forecast horizon $h$. Standard errors are HAC-consistent. 


\section{C2. Bond Risk Premia}

Table C2 shows that a higher US government surplus-to-debt ratio is associated with a lower term premium and a lower Cochrane and Piazzesi (2005) bond factor, both of which reflect the risk premia of long-term US government bonds. The US government surplus-to-debt ratio alone explains $35 \%$ of the variation in the term premium, and $37 \%$ in Cochrane and Piazzesi (2005) bond factor. Consistent with the model's prediction, this result suggests that US investors have a lower risk premium when the US government surplus-to-debt ratio is high.

\section{Table C2-US Fiscal Cycle Explains Bond Risk Premia}

\begin{tabular}{|c|c|c|c|c|c|c|c|c|}
\hline & \multicolumn{8}{|c|}{ Dependent variable: } \\
\hline & \multicolumn{4}{|c|}{ (1)-(4): Term Premium } & \multicolumn{4}{|c|}{ (5)-(8): Cochrane-Piazzesi Factor } \\
\hline & $(1)$ & $(2)$ & $(3)$ & $(4)$ & $(5)$ & $(6)$ & $(7)$ & $(8)$ \\
\hline US Government Surplus-Debt Ratio (\%) & $\begin{array}{c}-0.63^{* * *} \\
(0.10)\end{array}$ & & & $\begin{array}{r}-0.28^{*} \\
(0.15)\end{array}$ & $\begin{array}{c}-7.37^{* * *} \\
(1.21)\end{array}$ & & & $\begin{array}{r}-3.71^{*} \\
(1.90)\end{array}$ \\
\hline Forward Premium (\%) & & $\begin{array}{c}-0.97^{* * *} \\
(0.23)\end{array}$ & & $\begin{array}{c}-0.78^{* *} \\
(0.31)\end{array}$ & & $\begin{array}{c}-10.46^{* * *} \\
(3.19)\end{array}$ & & $\begin{array}{c}-8.20^{* *} \\
(3.52)\end{array}$ \\
\hline US Government Debt-GDP Ratio (\%) & & & $\begin{array}{c}0.001 \\
(0.001)\end{array}$ & $\begin{array}{c}0.002 \\
(0.001)\end{array}$ & & & $\begin{array}{l}0.02^{* *} \\
(0.01)\end{array}$ & $\begin{array}{c}0.02 \\
(0.02)\end{array}$ \\
\hline US Treasury Basis (bps) & & & & $\begin{array}{c}0.001 \\
(0.004) \\
\end{array}$ & & & & $\begin{array}{c}0.01 \\
(0.05) \\
\end{array}$ \\
\hline Observations & 133 & 133 & 133 & 118 & 133 & 133 & 133 & 118 \\
\hline $\mathrm{R}^{2}$ & 0.35 & 0.36 & 0.02 & 0.47 & 0.37 & 0.32 & 0.05 & 0.50 \\
\hline
\end{tabular}

Note: Term premium is 5-year US government debt yield minus 1-year US government debt yield; CochranePiazzesi factor is the single factor defined in Cochrane and Piazzesi (2005). Standard errors are HACconsistent. ${ }^{*} \mathrm{p}<0.1 ;{ }^{* *} \mathrm{p}<0.05 ;{ }^{* * *} \mathrm{p}<0.01$.

\section{C3. Dollar Carry Trade}

Lustig, Roussanov and Verdelhan (2014) construct a dollar carry trade that buys foreign currencies against the dollar whenever the US forward premium is below 0, which typically occurs during U.S. recessions, and shorts foreign currencies against the dollar otherwise. This simple strategy produces an annual Sharpe ratio in excess of 0.50 , higher than those on both the carry trade and the U.S. stock market.

Table C1 shows that US government surplus-to-debt ratio alone explains $43 \%$ of the variation in the forward premium. So, whenever the dollar carry trade takes a long position on foreign currencies because the US forward premium is negative, the US government surplus-to-debt ratio is also likely to be low.

Therefore, I can construct a dollar fiscal strategy that buys foreign currencies against the dollar whenever the US government surplus-to-debt ratio is below $-1 \%$, and shorts foreign currencies otherwise. The threshold $-1 \%$ roughly 
corresponds to the value of the US government surplus-to-debt ratio that corresponds to a forward premium of 0 in the linear fit. The result is robust to other choices of the threshold.

Table C3 reports the results using different thresholds. The dollar fiscal strategy has a similar quarterly average excess return and a similar quarterly Sharpe ratio as those of the dollar carry strategy. Its return is also strongly correlated with the return of the dollar carry strategy. When I control for the dollar fiscal strategy's returns, the dollar carry strategy does not have statistically significant abnormal returns.

\section{Table C3-The Dollar Carry Strategy and the Dollar Fiscal Strategy}

\begin{tabular}{l|cccc}
\hline \hline Strategy & Average Return (\%) & Sharpe Ratio & $\alpha$ & $\beta$ \\
\hline Dollar Carry & $1.00(0.35)$ & $0.24(0.09)$ & & \\
Dollar Fiscal, Threshold $-1.50 \%$ & $0.95(0.36)$ & $0.23(0.09)$ & $0.39(0.29)$ & $0.64(0.10)$ \\
Dollar Fiscal, Threshold $-1.25 \%$ & $1.12(0.35)$ & $0.27(0.09)$ & $0.19(0.26)$ & $0.72(0.09)$ \\
Dollar Fiscal, Threshold $-1.00 \%$ & $1.12(0.35)$ & $0.27(0.09)$ & $0.20(0.26)$ & $0.72(0.09)$ \\
Dollar Fiscal, Threshold $-0.75 \%$ & $0.95(0.36)$ & $0.23(0.09)$ & $0.31(0.28)$ & $0.72(0.09)$ \\
Dollar Fiscal, Threshold $-0.50 \%$ & $0.78(0.36)$ & $0.19(0.09)$ & $0.46(0.28)$ & $0.69(0.09)$ \\
\hline
\end{tabular}

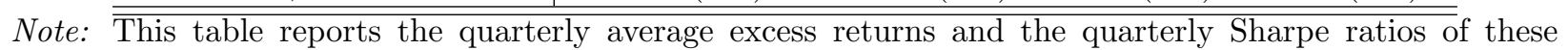
strategies. The coefficients $\alpha$ and $\beta$ are obtained from the regression of the dollar carry strategy's returns on each dollar fiscal strategy's returns. Standard errors in parenthesis are from bootstrapping. 